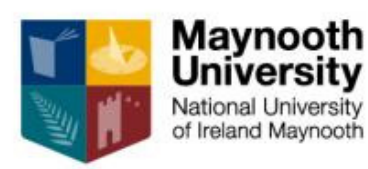

Department of Economics Finance \& Accounting

Working Paper N297-20

\title{
Role of corporate governance and lifecycle in determining payout precommitment in an emerging economy
}

\begin{tabular}{|c|c|c|}
\hline Thomas Flavin & Abhinav Goyal & Thomas O'Connor \\
Department of Economics, & Department of Accounting and & Department of Economics, \\
Finance and Accounting & Finance, & Finance and Accounting \\
Maynooth University, & Maynooth University, \\
National University of Ireland & Cork University Business & School, \\
Maynooth, & University College Cork, & Maynooth, \\
Maynooth, & Cork, & Maynooth, \\
Co. Kildare, & Ireland & Co. Kildare, \\
Ireland. & & Ireland. \\
& & \\
& & \\
\hline
\end{tabular}

\begin{abstract}
We analyze the role of firm-level corporate governance in determining the precommitment payout policy of emerging market firms and investigate if there is a precommitment lifecycle effect. Unlike previous studies for the U.S. firms, we only find evidence of precommitment among relatively wellgoverned firms, who combine good governance with large dividend payouts to shareholders and large debt-related repayments to creditors. We also document a strong precommitment lifecycle effect. Firms in the growth and mature stages of their lifecycle tend to use both debt and dividends to precommit to investors, with an increasing proportion of dividends in total payout measures. Our results are robust to an array of control variables, alternate payout proxies, firm-level corporate governance and addresses any potential endogeneity concerns in the sample.
\end{abstract}

Keywords: Precommitment payout, corporate governance, lifecycle effects, emerging market. JEL: G32; G35. 


\section{Introduction}

In this paper, we examine the payout behavior of emerging market firms by focusing on three channels of cash distribution - cash dividends, interest expense and share repurchases - and various mixes of these payout channels. In particular, we focus on two issues. Firstly, we test if the firm-specific level of corporate governance is a significant determinant of corporate precommitment policy, i.e. do firms in emerging countries use these channels of cash disbursement as a tool to assuage investors' concerns about corporate governance. John et al. (2015) establish a relationship between payout precommitment and corporate governance for U.S. firms by showing that firms with relatively poor governance distribute a higher proportion of earnings as a combination of dividends and interest on debt contracts (akin to the agency substitution model of La Porta et al., 2000). However, the question as to whether this relationship is also manifest in the payout policies of emerging market firms is unresolved. While the weak institutional environment of an emerging market provides incentives for firms to pursue such strategies, there are other features of these markets (as argued below) which may restrict their efficacy. Furthermore, the outcome model of La Porta et al. (2000) says that payout precommitment may be practiced not just by poorly governed firms, but also by well-governed firms using a combination of good governance, large dividend payouts to shareholders, and high interest and principal payments to creditors. Secondly, we investigate if our precommitment measures vary over the firm lifecycle and thus, look for evidence of a lifecycle effect in the payout precommitment.

Dividend variations over the corporate lifecycle have been documented for both strong governance (DeAngelo et al., 2006 and Denis and Osobov, 2008) and weak governance (Brockman and Unlu, 2011; Goyal et al., 2020) regimes but the evolution of the precommitment mechanism (i.e. the mix of cash dividends, debt interest repayments and share repurchases) over the lifecycle remains an unexplored issue. ${ }^{1}$ The goal of this paper is to provide empirical evidence on these two issues in the context of an emerging market, whose country-level corporate governance is weak relative to the U.S.

\footnotetext{
${ }^{1}$ The ratio of retained to total equity (RE/TE) is often used as a proxy for the firm lifecycle and is included as a control variable in the analysis of John et al. (2015). However, they do not explore its implications for the lifecycle. In this paper, we explicitly focus on the lifecycle effect, using a superior method of lifecycle classification, namely the Multiclass Linear Discriminant Analysis (MLDA) of Faff et al. (2016) which is discussed in Section 2.3.
} 
(and developed markets, in general) and where firms need to signal their commitment to investor protection to both current and prospective external stakeholders.

Our results show that the precommitment strategies of emerging market firms are quite different from their developed market counterparts. Unlike the U.S. market, where cash payouts are decreasing in corporate governance (John et al., 2015), we find that the payout behavior of emerging market firms is more consistent with an outcome model for both cash dividends and debt, i.e. there is a positive relationship between corporate governance and both dividends and debt. While the proportion of dividends and interest expense in total payout is invariant to corporate governance, the amounts of both variables increase. It appears that better-governed firms reinforce their commitment to better protect stakeholders by paying higher dividends and spending more on debt-related payments than relatively poorly governed firms do. This finding is robust to sub-dividing our sample into above- and belowmedian levels of foreign ownership, size and age, as well as splitting the sample into firms that are cross-listed or not, and those that belong to a business group or not. Secondly, we find that emerging market firms tend to use a combination of both debt and cash dividends to signal their commitment towards protecting stakeholders, which is also consistent with U.S. firms (John et al., 2015). Finally, we find an interesting precommitment lifecycle effect with a significant change in the payout mix as firms progress along the lifecycle spectrum. In particular, firms tend to distribute a higher proportion of payout in the form of regular cash dividends, as dividends tend to increase and with the reduction in debt, the interest expense decreases. While there is a very high likelihood of firms using a combination of both cash dividends and debt, there is an increasing likelihood of using more dividends over the lifecycle.

Firms incorporated in countries with relatively low levels of corporate governance have an incentive to adopt precommitment payout strategies to reassure stakeholders that they are committed to investor protection (La Porta et al., 2000; Brockman and Unlu, 2011; Goyal et al., 2020). Strategies that signal a commitment to disburse cash holdings through debt repayments and cash dividends are popular 
as they avoid the upfront costs of formal bonding mechanisms. ${ }^{2}$ Since both debt and cash dividends involve a level of precommitment to make regular payments to external stakeholders in the firm, they can each serve to mitigate managerial expropriation of the firm's assets. The precommitment is explicit in the case of contractual debt obligations. The borrower commits to make regular repayments for a specified period and the debt contract specifies penalties for non-payment. With regard to dividends, the precommitment is implicit and stems from managers' aversion to cutting dividends due to the adverse investor reaction generated by such an action (Brav et al., 2005). Myers (2000) shows that a self-interested manager will optimally agree to an implicit dividend contract in exchange for investors' continued funding of the firm, while Brav et al (2005) argues that the manager optimally continues dividend payments due to the need to secure outside funding for future projects. John et al. (2015) identifies a commitment hierarchy with regular cash dividends at the top, followed by debt obligations, and finally share repurchases and other irregular dividends at the bottom. ${ }^{3}$

Generally, emerging market firms are characterized by poor investor protection, weak legal rights, and poor corporate governance (La Porta et al., 1997). Korea fits this description and, as a newly liberalized market over our sample period (1998-2004), affords us an interesting case study of how emerging market firms may use corporate payout policy to overcome institutional barriers to investment. ${ }^{4}$ Thus, on theoretical grounds, this institutional setting provides incentives for firms to

\footnotetext{
${ }^{2}$ There are a range of bonding mechanisms that require firms to improve their formal governance. For example, firms in markets with weaker security laws may commit to bond for better protection of shareholders by "renting" superior governance by cross-listing on the stock exchanges of foreign countries (see Karolyi, 2012). Although effective, these strategies impose a cost on the firm, which may be sufficiently high to discourage some firms from undertaking them (Doidge et al., 2007). Alternatively, firms can remain at home, and migrate to a listing segment on their home stock exchange, which demands an adherence to stricter governance standards e.g. Bovespa in Brazil, and what used to be the KSE and Kosdaq Stock Exchanges in South Korea (see Black et al., 2014; and Dewenter et al., 2005; Espenlaub et al., 2020). For a review of precommitment mechanisms, see Ribstein (2005).

${ }^{3}$ Of course, the use of debt or dividends as a precommitment device may create other agency problems. For example, while debt can limit managerial discretion with respect to the free cash flow (Jensen and Meckling, 1976), it may also contribute its own layer of shareholder-bondholder conflicts due to restrictive debt covenants limiting the firm in pursuing shareholder wealth maximizing projects. Similarly, cash dividends reduce free cash flow but are less likely to create shareholder-bondholder tensions due to debt payments being prioritized.

${ }^{4}$ In order to rule out the possibility that our results are driven by our choice of country, Section 4 presents results from repeating our analysis for a sample of Indian firms (another emerging market for which we have access to firm-level governance data from Black et al., 2014). These results remain qualitatively and quantitatively similar to those for Korean industrial firms.
} 
precommit to the better protection of minority stakeholders. Our decision to focus on Korea is motivated by a number of factors. Firstly, it is a relatively large emerging market that underwent considerable change over our study period. In the immediate aftermath of the Asian crisis, the Korean government sought to restructure its economic model and move away from the Chaebol system of cross-ownership and encouraged reforms to promote more dispersed ownership and decentralization of economic power. One of the key changes was the opening up of the stock market to foreign investors. The relative underdevelopment of domestic capital markets in emerging economies creates a greater need for firms to access international capital (La Porta et al., 1997) and, even though Korea began the liberalization process in 1992, it was not until 1998 that restrictions on foreign ownership were finally abolished. International investors responded favorably to the opening up of the Korean market and the value of shares in foreign ownership more than trebled between 1996 and $2004 .{ }^{5}$ Similarly, share repurchases underwent significant change over our sample period. Initially, they were legalized with a $5 \%$ limit in 1993 and that limit was ultimately dropped in 1998, allowing firms the possibility to distribute cash by this mechanism without the precommitment implied by cash dividends. Secondly, compared to other emerging markets, the quality and reliability of the Korean stock market and corporate governance data have seen it become the focus on many influential country-specific studies, such as Black et al. (2006) and Bae and Goyal (2010) among others. Specifically, for our purposes, the considerable cross-sectional firm-level variation in our measure of corporate governance, make it an ideal candidate to analyze the relationship between payout precommitment and governance in Korea.

Korean firms have a range of mechanisms that they can use to signal their commitment to protect its minority stakeholders. There are formal bonding strategies like cross-listing on international exchanges and thereby committing to greater levels of disclosure and transparency. Despite its attractions, relatively few Korean firms chose to seek an international cross-listing (Sarkissian and Schill, 2003). Licht (2004) argues that the cultural distance between Korea and the U.S. may dilute the bonding benefits of international cross-listings for Korean firms. However, Dewenter et al. (2005) found

\footnotetext{
${ }^{5}$ Please refer to Flavin and O'Connor (2017) and references therein for a more detailed discussion on the growth and internationalization of the Korean stock market post liberalization.
} 
that the development of a second local stock exchange, the KOSDAQ, with more rigorous reporting and disclosure requirements was successful in delivering local bonding benefits.

Our focus is on precommitment through corporate payout policy in an emerging market and this has received relatively little attention in the literature. Studies that analyse the relationship between corporate governance and payout policy tend to focus solely on dividend payouts (Hwang et al., 2013; Flavin and O'Connor, 2017; Goyal et al., 2020) or on debt (Kim, 2015; Goodell and Goyal, 2018), but not on the individual component of the total payouts. This paper goes beyond that and analyses not only the precommitment through dividends, but also precommitment through debt payments, share repurchases and various mixes of all three payout mechanisms.

Even though, as argued above, post-liberalization Korea represents a ripe setting for the implementation of payout strategies to reassure existing and potential stakeholders, the empirical evidence on this issue for emerging markets is mixed. Consistent with the type of precommitment found in the payout behavior of U.S. firms, Lozano et al. (2019) shows that Brazilian firms use less dividends and debt once they migrate to the premium Novo Mercado listing level, which imposes more onerous governance requirements. In contrast, Chang et al. (2018) present a multi-country study of the relationship between dividends and corporate governance (using country-level measures of governance) and finds that the outcome model is more consistent with the dividend policy of emerging market firms (i.e. dividends increase with governance), than the substitution model which would be expected if firms adopt U.S.-style precommitment policies. Furthermore, cultural factors may deter Korean firms from pursuing payout precommitment policies. We know from the existing literature that traditionally Korean firms had a weak dividend culture (Aivazian et al., 2003), despite the evidence that international investors tend to concentrate their investment in firms that pay large dividends (Jeon et al., 2011). Furthermore, Knyazeva and Knyazeva (2014) show that the reaction to dividend cuts by emerging market firms is more negative than those in developed market firms. Thus, the implicit precommitment of dividends is likely to be even stronger in emerging markets, making Korean firms more cautious about initiating or increasing dividend payouts. Hence, the incentive to precommit through cash dividends may have changed post-1998. Additionally, some changes may be instigated by the foreign 
investors themselves, e.g. post-liberalization, Jeon et al. (2011) show that foreign investors have forced Korean firms to pay larger dividends.

The type of precommitment may also be different from the U.S., due to a historical greater reliance on debt finance, and bank debt in particular, among Korean firms (Fan et al., 2012). ${ }^{6}$ Harvey et al. (2004) emphasize the benefit of using debt to curb agency problems in emerging markets, thus making it an attractive precommitment tool. On the other hand, the precommitment benefits of debt may be limited due to difficulties in enforcing debt contracts in emerging economies, especially for non-domestic debtholders (Djankov et al., 2007). Finally, share repurchases became an increasingly common distribution channel post liberalization (Jeon et al., 2011), suggesting that consolidation of ownership may have been the priority of some firms. Therefore, our focus is on precommitment through payout policy in a period where the lifting of restrictions and opening up of markets afforded firms the opportunity to voluntarily adopt policies to signal their commitment to investor protection.

The extant literature provides evidence of lifecycle effects in corporate capital structure (Kieschnick and Moussawi, 2018) and hence in the components of our payout precommitment measures. DeAngelo et al. (2006) propose a lifecycle theory of dividends and provide supporting empirical evidence. Simply put, in the initial stages of the firm's lifecycle, when the investment opportunity set exceeds the internally generated capital of the firm, dividends tend to be low. In contrast, as firms mature and retained earnings exceed the investment opportunity set, they pay higher dividends to mitigate expropriation of free cash flows.

The empirical evidence on the use of debt financing over the lifecycle is ambiguous. The early evidence suggested that the amount of debt grows as firms age (Hovakimian et al., 2001; Sundaresan et al., 2015) but more recent evidence from Kieschnick and Moussawi (2018) casts doubt on this evolution process. They show that while the likelihood of debt financing increases with firm age; the amount of debt decreases. Likewise, the empirical evidence regarding share repurchases over the lifecycle is unclear. While the amount of share repurchases is generally found to be increasing over the

\footnotetext{
${ }^{6}$ Historically, bank financing dominates bond financing in Korea, while the reverse is true in the U.S (Goodell and Goyal, 2018). In theory, the monitoring provided by banks is greater than monitoring by bond markets, which suggests that bank financing plays a larger precommitment role.
} 
lifecycle (e.g. Coulton and Ruddock, 2011), evidence pertaining to their growth relative to cash dividends has produced conflicting results. For example, in the U.S. context, John et al. (2015) find that cash dividends increase faster than share repurchases as firms mature, while Stepanyan (2011) argues that when firms use a combination of cash dividends and share repurchases as distribution channels, there is a sequencing in the payout mechanism. The proportion of dividends to repurchases is typically zero in early stages as firms use neither payout channel, nor jumps to one in intermediate stages as firms use dividends only. When they begin to fall in later stages, repurchases are added to the payout mix. Therefore, we need to empirically establish the lifecycle pattern of our precommitment measures for emerging market firms.

The rest of the paper is structured as follows. Section 2 contains a description of the data and provides some preliminary univariate analysis. Section 3 reports the results of a multivariate analysis. Section 4 reports the results of a robustness check by repeating the analysis for a sample of Indian firms over a later time-period. Finally, Section 5 concludes.

\section{Data}

In this section, we describe the sample of firms, and the variables utilized in this study. Our independent variables consist of an extensive set of firm-level financial and accounting variables, capturing a wide range of firm-specific characteristics, as detailed below and summarized in Table 1 . We obtain our firm-level data from Worldscope via Thomson One Banker Analytics. In order to mitigate against potential survivorship bias affecting our results, we source a full list of Korean firms, both dead and alive, over the period from 1998 to 2004. Our sample stops in 2004 because we use the Black et al. (2014) corporate governance scores that are only available over this period. ${ }^{7}$ Consistent with other reputable studies on payout policy (e.g. Fama and French, 2001; DeAngelo et al., 2006; Denis and Osobov, 2008), we drop the firms in the financial (SIC Code: 6000-6999) and utility (SIC

\footnotetext{
${ }^{7}$ We are thankful to Prof. Bernard Black for sharing his corporate governance data on South Korea.
} 
Code: 4900-4949) sectors, foreign firms, and firms with negative total equity, missing retained earnings, and missing any of the control variables.

\subsection{Dependent variables}

Firms can potentially return cash to the providers of capital in the form of dividends and share repurchase to shareholders, and debt repayments (interest and borrowed principal) to creditors. We measure cash distributed to shareholders in the form of dividends-to-assets and share-repurchase-toassets, and to debtholders in the form of interest-expense-to-assets. We also analyze the level of debt using the book debt (financial debt to book assets) and the financial debt to capital ratios, where capital is defined as the sum of financial debt and shareholders' equity. We follow John et al. (2015) and construct our dependent variables to capture the proportion of dividends in total payout. "Div/Total" is the share of dividends in total payout, where total payout is the sum of cash dividends, share repurchases, and interest expense. Share repurchases, which tend to be irregular events and hence involve no future commitment to repeat, are omitted from the "Div/Commit" variable. Hence, this is the ratio of dividends to the sum of dividends and interest expense disbursed by the firm in a financial year. Finally, "Div/Payout" is the proportion of the dividends paid as a part of the total payout to the shareholders only (the sum of dividends and share repurchases).

We augment these measures with three binary categorical measures. "Commitment type 1" distinguishes between firms that use a combination of dividends and debt as opposed to those who use debt alone. Similarly, "Commitment type 2", separates firms that use a combination of dividends and debt from those who only use dividends. Lastly, "Payout type" focuses on firms' precommitment to shareholders, i.e. the non-contractual payout precommitment. "Payout type" is designed to capture differences between firms that use dividends (and possibly share repurchases) and those who only use share repurchases alone. Table 1 explains the coding and definition of these variables.

\subsection{Corporate governance}

To capture firm-level governance for publicly listed firms in South Korea, we rely on Black et al.'s (2014) Korea Corporate Governance Index (KCGI). The variable is constructed using non-public 
data from surveys conducted by the Korea Corporate Governance Services in South Korea between 1998 and 2004. The index includes 25 different governance elements distributed across five equally weighted sub-indices for Board Structure (Seven elements), Board Procedure (Twelve elements), Disclosure (Three elements), Ownership Structure (One element), and Shareholder Rights (Two elements). Most elements are binary (" 1 " if a firm has the attribute, " 0 " otherwise); while the continuous elements are scaled between zero and one. Within each sub-index, each element is equally weighted, and then each sub-index is scaled to run from 0 to 100 . The index is then computed as the average of the five sub-index scores.

We believe that our choice of the corporate governance index for Korea is both appropriate and suitable in an emerging market setting. Primarily, unlike the developed market governance indices which focus on anti-takeover defense mechanism for the firms (Gompers et al., 2003), the Korea Corporate Governance Index focuses on a broader range of processes and shareholder rights. Besides, we believe that in the presence of business group firms, the Chaebols (Baek et al., 2006), and complex ownership structures (La Porta et al., 1999) in South Korea, investor expropriation and not hostile takeover is of primary concern.

\subsection{Lifecycle indicators}

In last two decades, the finance literature has developed a number of firm lifecycle proxies. However, studies by von Eije and Megginson (2008), Banyi and Kahle (2014) suggest that some lifecycle proxies can lead to conflicting results. Therefore, the choice of lifecycle proxy is important and reliance on a single lifecycle proxy is probably not advisable. An alternative view is that some existing proxies may be open to a number of interpretations. Therefore, to address this issue, we use two lifecycle proxy measures. First, we use the Multiclass Linear Discriminant Analysis (MLDA), of Faff et al. (2016), to classify firms into one of four lifecycle stages, namely introduction-stage, growthstage, mature-stage, and shake-out/decline-stage, using the Dickinson (2011) lifecycle classification scheme. ${ }^{8}$ From here, we perform the following linear discriminant analysis:

\footnotetext{
${ }^{8}$ Dickinson (2011) classifies firms into one of five lifecycle stages, namely introduction (birth), growth, maturity, shakeout and decline based on the combined signs of net cash flows from operating, financing, and investing
} 
Where age is firm age, RE/TE is the ratio of retained earnings to total equity, Profit is return on assets (EBIT/Assets), and SGrowth is one-year sales growth. Stage is lifecycle stage. Using these variables, MLDA provides maximum separation between the four stages in the firm's lifecycle. ${ }^{9}$ Thus, MLDA is our preferred lifecycle indicator in this study.

Second, to test the validity of our results, we use the ratio of retained earnings to total equity (RE/TE) as proposed by DeAngelo et al. (2006). Total equity is the sum of retained and contributed equity. The rationale for using this variable as a proxy for firm lifecycle is based on the argument that young firms rely largely on contributed (external) equity since their retained equity is likely to be low. Therefore, they are expected to have low RE/TE ratios. In contrast, mature firms have large RE/TE ratios as their opportunities for profitable investment decline and net cash inflows from operations increase. This combination gives them greater access to internal funds (retained net cash flows from operations) and less need for contributed equity. However, in contrast to the proxies of Dickinson (2011) and the MLDA methodology, RE/TE does not explicitly classify firms into distinct lifestyle stages, as it specifies no objective cut-off point to delineate between lifecycle stages. To address this drawback of RE/TE, we follow Owen and Yawson (2010) to create three lifecycle stages based on RE/TE quartiles. We classify firms as young- and old-stage firms if they are found in the smallest and largest RE/TE quartiles, respectively. Firms in the second and third quartiles are designated as mature-stage firms.

\subsection{Control variables}

In all regressions, we control for a range of firm-specific variables related to payout and corporate governance that have been shown to be important in other studies. These variables are cash holdings (von Eije and Megginson, 2008; Goyal et al., 2020), profitability (Denis and Osobov, 2008),

activities. Net cash flows can be positive or negative, resulting in eight possible cash flow combinations. Like others, we group shakeout and decline stages together to create four lifecycle stages.

${ }^{9}$ Faff et al. (2016, pp. 98) provide arguments in favor of using MLDA as a superior lifecycle classification system. 
investment opportunities (Denis and Osobov, 2008; Fama and French, 2001), firm size (Fama and French, 2001), asset tangibility (Aivazian et al., 2003), and cash flow uncertainty (Chay and Suh, 2009). In the extant literature, there is little consensus on the payout policies of Chaebol (business group) and non-Chaebol (independent) firms. Recently Flavin and O'Connor (2017) find no significant difference in dividend payout between the two groups, while Hwang et al. (2013) conclude that dividends paid by Chaebol firms are lower than independent firms. However, irrespective of that, business group firms, and in particular Korean Chaebols have been notorious for expropriating minority shareholders and other investors (Baek et al., 2006). Hence, we also include a business group dummy, which is one if the firm belongs to a Chaebol. Across all the regressions, we also include year and industry dummies.

\subsection{Sample description and preliminary statistics}

In order to account for the outliers, we winsorize variables defined as ratios at upper and lower $1 \%$ levels. Table 1 presents a detailed description of all the dependent, corporate governance, lifecycle and control variables. It also includes some basic summary statistics for each variable over the sample period.

\section{[Insert Table 1 about here]}

Table 2 reports a breakdown of the data in several dimensions. As reported in Panel A, after applying all the constraints discussed in the last section, we are left with 293 industrial firms from South Korea $^{10}$ which account for 1,135 firm-year observations in total; over a seven-year sample period between 1998 and 2004 for which we have access to the South Korean corporate governance index from Black et al. (2014). Panel B of Table 2 presents an overview of the payout policies of these firms. We observe that most South Korean firms pay cash dividends (93\% of firm-year observations have positive dividends) and have contractual debt obligations (98\%), but a smaller number of firms also use share repurchase to distribute profit to shareholders $(43 \%)$. The proportion of Korean firms paying dividends is in line with the extant literature (Goyal and Muckley, 2013). Furthermore, firms are more

\footnotetext{
${ }^{10}$ Our sample size for South Korea is comparable with many existing studies for the same sample period, e.g. Mitton (2002) uses 144 Korean firms, Claessens et al. (2000) uses 345 firms, and Denis and Osobov (2008) uses 155 firms. Worldscope coverage of Korean firms in 1997 was just 318 firms, and in general; Worldscope sample accounts for about $95 \%$ of the total market capitalization for any country (Denis and Osobov, 2008).
} 
likely to use a combination of dividends and interest-bearing debt (56\%) rather than dividends and share repurchases $(36 \%)$.

Panel C of Table 2 focuses on corporate governance and shows that firm-level governance, like in many other emerging markets, is relatively low for South Korean firms. It also reveals a great deal of cross-sectional variation across Korean firms. The firm-level scores range from 11.28 to 84.60 (on a scale of $0-100$ ), with an average (median) score of 35.82 (34.08). Only $5 \%$ of the firms exhibit a total governance score of 57.62 or higher.

Panel D of Table 2 analyzes the data over firm MLDA lifecycle stages. The distribution of firmyear observations across lifecycle stage is not uniform, with fewer firms-years allocated to the birth (17.5\%) and growth (15\%) stages than the mature (37.1\%) and shake-out/decline (30.4\%) stages. The remainder of Panel D presents the median firm-level characteristics in each lifecycle stage. ${ }^{11} \mathrm{We}$ observe an inverted u-shape for many variables. For example, growth opportunities, profits, cash holdings and even RE/TE increase from birth until maturity but taper off in the shake-out/decline stage. The relationship between external financing need and firm lifecycle is u-shaped, as external financing need is greatest for birth- and shake-out/decline stage firms.

Panel E of Table 2 reports median corporate governance and firm payout measures in calendar time. Over the sample period, we observe significant increases in dividend payout, and decreases in debt usage, and improvements in overall corporate governance. Panel F reports median payout measures by corporate governance quartile and is supportive of the outcome model and payout precommitment by well-governed firms. Each of dividends, debt (but not interest expense), div/total, and div/commit increases significantly with corporate governance.

In summary, the descriptive statistics in Table 2 document that in comparison to mature/oldstage firms, young/growth-stage firms are smaller, with higher growth opportunities, and limited profitability and cash holdings, resulting in higher external financing need. Also, as reported in the literature for other developed and developing markets (e.g. Fama and French, 2001; von Eije and

\footnotetext{
${ }^{11}$ As additional robustness analysis, we repeat our analysis with average firm-level characteristics in each lifecycle stage but do not find any notable difference. Results are available upon request.
} 
Megginson, 2008; Chay and Suh, 2009; Mitton, 2004), the payout policy in South Korea is relatively sticky. Once interest is paid to debtholders, managers prefer to pay cash dividends to the equity holders rather than implement share repurchase programs. There is evidence to support an outcome model for both dividend payouts and debt financing, and hence payout precommitment by better-governed firms. Firms complement their already good governance, with large dividend payouts to shareholders and large principal and interest payments to creditors.

[Insert Table 2 about here]

\section{Regression analysis}

Our regression-based analysis addresses three issues. Firstly, we analyze the determinants of the different cash distribution channels to the firms' stakeholders (i.e. dividends, debt repayments and share repurchases); focusing mainly on the role of corporate governance and lifecycle stage, while controlling for other factors. Secondly, we examine the determinants of our precommitment measures and analyze the likelihood of firms using combinations of dividends and debt as opposed to exclusively concentrating on either channel. Thirdly, we delve deeper into the driving forces of our results by analyzing the precommitment policies of Korean firms across different subsamples.

3.1 Effect of corporate governance on firm-level payout across the lifecycle

Empirical tests of payout precommitment are related to outcome and substitution models of dividends (and debt) and have been implemented in two forms. First, the seminal literature suggests that it is the level of dividends (and debt) which matters for precommitment, and proceed by regressing the level of dividends (and debt) on corporate governance scores, controlling for factors related to both dividends/debt and corporate governance (see La Porta et al. 2000; Mitton, 2004; Chang et al., 2018; and Chintrakarn et al., 2019, for dividends, and Jiraporn and Gleason, 2007; Goodell and Goyal, 2018, for debt). The substitution model predicts that payout precommitment should be stronger for poorly governed firms who substitute poor governance with abundant payouts to shareholders and creditors. In contrast, the outcome model predicts that it is well-governed firms who practice payout precommitment and complement good governance with large dividend and interest payments. The 
second method, proposed by John et al. (2015) suggests that it is payout mix ratios (e.g., dividends to the sum of dividends and interest payments), and not just the payout level, that matters for payout precommitment. They run their regressions with these ratios (defined above) as the dependent variables. Here, we use both approaches to test for payout precommitment in Korea.

We first estimate, by pooled ordinary least squares regression, the effect of corporate governance and lifecycle stage on each of our channels of cash distribution across the firm lifecycle. Table 3 presents our results for cash dividends (column 1), book debt (column 2), financial debt to capital (column 3), interest expense (to assets) (column 4) and share repurchase payout (column 5). ${ }^{12}$ In all model specifications, we control for firm-level factors, and time and industry fixed effects. The classification of lifecycle stage is determined using the MLDA approach. Payout precommitment under the substitution (outcome) model predicts that at least one of our dependent variables should be inversely (positively) related to corporate governance. The estimated coefficients on corporate governance supports the outcome model.

Corporate governance matters for corporate dividend payout policy. We observe a strong positive, and statistically significant relationship between governance and the dividend amount, lending statistical support for the outcome, and not the substitution model of dividend payout formulated by La Porta et al. (2000). Our findings are consistent with Mitton (2004) and Goyal and Muckley (2013), who finds support in favor of the outcome model for a sample of emerging market firms (which includes Korea). The dividend-governance relationship is economically significant. We observe that dividends paid by firms in the top governance decile are $46 \%$ larger than dividends paid by firms in the lowest dividend decile (median dividends-to-assets is $0.67 \%$ for firms in the lowest governance decile and $0.98 \%$ for firms in the highest governance decile). Firm lifecycle also has a strong influence on corporate dividend payouts. Mature-stage firms pay higher dividends than firms in any other lifecycle stage, and the difference is always statistically significant. These differences are economically important too. For example, the difference in dividends paid between firms in the mature- and growth-

\footnotetext{
${ }^{12}$ We use financial debt to capital together with book debt to measure firm debt use, because book debt is scaled by book assets, and as book assets includes accounts payable, book debt falls when accounts payable rises, all else equal. Welch (2011) advocates the use of financial debt to capital instead of book assets.
} 
stages is 0.161 (0.188 less 0.027 ) or 19\% of average dividends paid. Both Flavin and O'Connor (2017) highlight a similar dividend-lifecycle relationship for firms in Korea. Results for the other potential determinants of dividend policy are broadly in line with the extant literature. Dividend payout increases with profitability (Fama and French, 2001), and decreases with asset tangibility (Aivazian et al., 2003), leverage (von Eije and Megginson, 2008), and profit volatility (Chay and Suh, 2009). Interestingly, firms with higher investment opportunities are more likely to disgorge cash; both in the form of dividends, and share repurchase. This is consistent with Flavin and O'Connor (2017), who argue that Korean firms pay higher dividends as a strategy to enhance their reputation in capital markets, particularly among external investors. In a similar vein, smaller firms pay higher dividends compared to all other firms. Neither cash holdings nor Chaebol affiliation appear to have any effect on the dividend payout policy of the Korean firms.

In columns 2-4, we turn our attention to the determinants of debt financing and the interest expense arising from debt repayments. We establish a statistically significant relationship between corporate governance and each of our debt measures; book debt, financial debt to capital, and interest expense. Debt financing, like dividend payouts, appears to be an outcome of strong corporate governance. Our finding for Korean firms is in stark contrast to the negative leverage-corporate governance relationship uncovered for U.S. firms by Jiraporn and Gleason (2007). The influence of corporate governance on each of our debt measures is statistically significant. For example, a worst to best change in governance deciles, increases book debt by 0.10 or $50 \%$ ( 0.20 to 0.30$)$, and financial debt to capital by 0.17 ( 0.27 to 0.44 , or almost three quarters of one full standard deviation). Presumably, the increase in interest expense for well-governed firms occurs, not because of higher interest rates, but greater debt usage. There is also a strong lifecycle effect. As firms progress along the lifecycle spectrum, debt financing and interest expense tends to fall, which is consistent with the findings of Kieschnick and Moussawi (2018). As firms transition from birth-stage through to mature-stage, they rely less on debt financing (and perhaps, rely more on internal financing and maybe equity). The difference in financial debt (to capital) use between growth-stage and mature-stage firms is economically large $(0.15)$ or almost $43 \%$ of average financial debt to capital. Given the level of debt used by birth-stage firms, it is not surprising to see that interest expense is largest for these firms, and smallest for firms in the 
growth- and mature-stages, yet smallest for firms in the growth-stage. The difference in interest paid between birth- and growth-stage is large $(-0.972 \%)$ or almost $40 \%$ of average interest expense paid. This is plausible since many of these firms may have limited access to alternative sources of financing and are thus more likely to finance their investment activities through debt, resulting in higher interest expenses. These interest expenses drop significantly during later lifecycle stages as firms generate revenue and profits, enjoy reduced borrowing rates on debt, and gain greater access to alternative sources of capital. The signs on our control variables are broadly as expected with investment opportunities and cash holdings tending to reduce the interest expense (through either a reduced reliance on borrowing or lower interest rates or a combination of the two), with the opposite effect being recorded for cash flow uncertainty. None of the other variables appears to matter for interest expense. Interestingly, Chaebol firms use more debt compared to independent firms.

Finally, column 5 shows that, for share repurchases, our specification has little light to shed on their determinants. There is no evidence that the level of corporate governance or the lifecycle stage of the firm matters. The lack of a lifecycle effect is not surprising and can be explained by the noncommittal nature of the repurchase decision. For example, Brav et al. (2005) have already documented that managers consider share repurchases as a flexible form of cash disbursement to shareholders in the presence of cash surplus but without any commitment to repeat the exercise. Among the control variables, only firm size and investment opportunities has any statistical significance, albeit marginally so. The later variable is likely to be capturing the reputation building behavior of firms that has been already identified by Flavin and O'Connor (2017).

[Insert Table 3 about here]

\subsection{Effect of corporate governance and firm's lifecycle on firm-level payout precommitment}

Our preliminary findings from Table 3 are not supportive of the idea that firms use large dividend and debt payouts to substitute for poor governance. Rather, it is the outcome model, which prevails. However, since firms could potentially use debt and dividends, or a combination of the two, to signal their commitment to investor protection, it is essential to identify which of the two claimants (debtholders or shareholders) is relatively more important for our sample of Korean firms. Since these 
firms exhibit large cross-sectional variation in governance and lifecycle phase, we analyze their payout strategies in both dimensions. In Table 4, we present evidence on the implications of firm-level corporate governance and the lifecycle stage of the firm for the trade-off in the firms' choice to precommit using payments to debtholders versus shareholders. Model 1-3 report results from a pooled OLS regression of each of precommitment measures and columns 4-6 for the likelihood of various combinations of dividends, debt and share repurchases. Our results fail to find any significant relationship between our payout precommitment ratios and firm-level governance. In every case, across all three channels of cash distribution, it appears that corporate governance does not matter in the determination of the precommitment payout mix. This is in direct contrast with the results reported for the U.S. by John et al. (2015), where firms with weak corporate governance precommit through a combination of dividends and debt or through dividends rather than debt alone. ${ }^{13}$ Combining the evidence from Tables 3 and 4, we find no difference in the dividend/interest mix between weak- and strong-governed firms, but the level of dividends and debt is greater for better-governed firms.

However, we establish a strong relationship between precommitment and the financial lifecycle stage of the firm. While, firms in a more advanced phase of their lifecycle (either in the growth- or mature-stage) tend to disburse a higher proportion of total and committed payout through dividends in order to mitigate shareholder-manager agency conflict, there is not a simple monotonic increase across lifecycle stages. We note that in these precommitment measures, the proportion of payouts made through dividends increases up to the mature-stage but then declines during the shake-out/decline stage. The proportion of dividends does not statistically change as the typical firm progresses through the growth to the mature lifecycle stage, suggesting that the proportion of dividends in the total and committed payout ratios of firms in both intermediate lifecycle stages is unaltered. This is consistent with Flavin and O'Connor (2017) who show that Korean firms continue to use dividend policy to build reputation capital throughout their growth and mature stages of the lifecycle. It appears that, when financial resources allow, firms use both debt and cash dividends to signal their quality to external investors. The observed fall off in dividends during the final (decline/shake-out) stage may be simply

\footnotetext{
${ }^{13}$ Our findings are robust to using different governance sub-indexes.
} 
due to precommitment becoming a less important issue for the firm. Furthermore, as firms shrink, they have a declining ability to generate the required cash to maintain dividends at their growth and maturity levels, while legally binding debt repayments may be increasingly financed by the proceeds of asset liquidations. The 'Commitment Type 1 and 2' variables reinforce the story. Relative to the birth lifecycle stage, firms at any other point on their lifecycle are more likely to use a combination of dividends and debt rather than debt alone, but they are not statistically different to each other, while the likelihood of using a combination of dividends and debt rather than dividends alone is largely unchanged across the lifecycle. As expected in Korea, where share repurchases are not as common as other forms of cash distribution to stakeholders, dividends relative to share repurchases increases after the birth stage but is not significantly different across subsequent lifecycle stages.

Generally, the control variables enter with the expected sign. Firms with larger contributed equity, cash surplus and lower earnings uncertainty tend to have a positive impact, on both the likelihood of dividend payment and the proportion of dividends in total payout to external claimholders. The positive influence of the investment opportunities on the dividend payout decision and amount aligns with the previously noted reputation building behavior of Korean firms (Flavin and O'Connor, 2017).

\section{[Insert Table 4 about here]}

Table 4 fails to find any support for the substitution model and contrasts sharply with the evidence presented in John et al. (2015) for developed country firms. To ensure that our results are robust and representative of Korean corporate payout policy, we delve deeper and examine the relationship between payout precommitment and corporate governance across a number of different subsamples of firms. We hypothesize that the incentive to precommit is not the same for firms that have different characteristics such as the level of foreign ownership; being cross-listed abroad; small, and not belonging to a business group. The literature shows that foreign ownership (Choi et al., 2007), international cross-listings (Coffee, 1999), and firm size (Black and Kim, 2012) are all associated with better governance and bonding benefits. Chaebol affiliated firms benefit from access to internal capital markets and reduced financing constraints (Almeida et al., 2015), and thus in theory have less need to use financing policies to precommit. Finally, we divide the sample by firm age. This may be interpreted 
as a proxy for firm lifecycle (albeit, an imperfect one) or it may simply be picking up the difference in future growth opportunities. A priori, we expect that low-governance, early-stage firms are more likely to use dividends to substitute for governance shortcomings as they try to build reputation in the capital markets and finance their growth opportunities. We focus on each characteristic separately and estimate the difference of the precommitment-governance relationship for firms with above- and below-median levels of each. Table 5 reports our results.

Splitting the sample of firms between above- and below-median levels of foreign ownership produces some interesting results. On first inspection, and focusing on the ratios, it appears that there is evidence of different payout precommitment behavior between the two groups. Our results suggest that those firms with relatively low levels of foreign investment precommit using dividend payouts (the agency substitution model), i.e. poorly governed firms use a greater share of dividends relative to total payouts to precommit to protect their minority shareholders. In contrast, better-governed firms, consistent with what we observed in Table 3, pay a greater share of total payouts as dividends. The same is true for both groups when analyzing the other precommitment measures, though the negative coefficient in the regression for Div/Commit is not statistically significant. However, focusing on the levels of the variables, it is evident that the negative coefficients on corporate governance for firms with low levels of foreign ownership do not arise from a substitution of debt for dividends. Rather, the regressions with the level of dividends to assets and interest expense to assets as dependent variables, reveal that both variables are increasing in corporate governance (the prediction of the outcome model) and the negative coefficient in the regressions for the ratios comes about because the interest expense variable is more sensitive (increases faster) than dividends to governance changes. Hence, these results strengthen the finding that it is the better-governed firms who use precommitment as a signal to investors by paying larger dividends and larger interest payments to their creditors. Exclusively focusing on ratios in the analysis would have led to an incorrect conclusion that poorly governed firms behave in accordance with the substitution model of dividends and debt.

The findings using cross-listing status, firm size, and business group are less definitive, but nevertheless, follow a similar pattern. Any evidence that appears to support the substitution model (e.g. when we split firms by age), only occurs in the regressions using a ratio as its dependent variable. All 
the evidence pertaining to the amount of dividends and the amount of debt-related payouts is consistent with the outcome model.

$$
\text { [Insert Table } 5 \text { about here] }
$$

Finally, we investigate if there are any important differences in payout policy between the lifecycle stages. In unreported tests, we estimate separate dividend-corporate governance regressions for each MLDA lifecycle stage but fail to find any evidence of a precommitment effect. We also proxy for the lifecycle using the continuous RE/TE variable and interacting it with corporate governance, but the interactions terms are never statistically significantly different from zero. Consequently, we conclude that there are no significant changes to the precommitment mechanism across the lifecycle.

\section{Robustness checks}

\subsection{Potential endogeneity issues}

As shown in other studies (Jiraporn et al., 2011; Chang et al., 2018; and Chintrakarn et al., 2019), there is a potential issue of endogeneity with our measure of corporate governance. To address this, we re-estimate our regressions using a two-stage least squares (2SLS) estimation approach to replicate the main results of our paper. Specifically, we follow Jiraporn et al. (2011) and Chang et al. (2018) in using the industry median governance as our instrument for firm-level corporate governance. In the first stage, we regress firm-level corporate governance on our proposed instrument and all other right-hand side variables from our original regression equation. In the second stage, we take the predicted value from the first stage and use it to replace the firm-level corporate governance in our econometric specification.

The first-stage regression finds a strong, positive and statistically significant relationship between firm-level corporate governance and industry median governance, consistent with Jiraporn et al. (2011) and Chang et al. (2018). The F-test decisively rejects the null hypothesis that coefficients on the instruments are jointly zero. We then proceed to the second stage and re-run the regressions with the predicted value from stage one as our measure of corporate governance. Our findings are generally 
consistent with earlier results, especially so for the precommitment ratios and are presented in Tables 6 and 7.

Table 6 presents the main results corresponding to our earlier Tables 3 and 4 . We first focus the effect of corporate governance on the level of dividends, share repurchases and debt-related variables. Results of the 2 SLS estimation are not statistically significant, suggesting that there is no relationship between our dependent variables and corporate governance. Even this result suggests that there is a difference between Korea and the U.S. as we find no evidence to support the substitution model of dividends or debt, as implied by the results for the U.S. in John et al. (2015). Given that the main focus of the paper is on the composition of the payout, we next analyze the payout precommitment ratios used, for their U.S. study, by John et al. (2015). The 2SLS estimates confirm that the instrument is not statistically significant in determining our payout ratios or the type of precommitment strategy employed by the firm. This is consistent with results reported in Table 4 and thus confirms that in the overall sample of Korean firms, there is no relationship between precommitment payout ratios and firmlevel corporate governance.

We then analyze the precommitment payout policies of different subsets of firms, with the sample divided between above- and below-median levels of certain firm characteristics, and also divided between cross-listed and not cross-listed as well as belonging to a business group or not. In Table 7, the results are robust to our measure of corporate governance. ${ }^{14}$ With 5 dependent variables and 5 different characteristics, we re-run 25 regressions. In 23 of these, our results are unchanged or stronger (i.e. we have the same sign as before but it is now statistically significant). In the other cases, the variables become statistically insignificant but this does not confound our main conclusion. The story that emerges is supportive of the outcome model, especially among larger firms, older firms, firms with higher levels of foreign ownership, and those that belong to a business group. For the other group in each category, there is also support for the outcome model despite an often-negative coefficient on

\footnotetext{
${ }^{14}$ To conserve space, Table 7 only presents the results when we divide the sample between above- and belowmedian level of foreign ownership. The results for the other subsamples are qualitatively the same as those in Table 5 and are presented in Appendix 1.
} 
the corporate governance instrument. The negative sign does not imply a substitution effect but rather than the denominator (debt) is increasing faster than the numerator (dividend).

[Insert Tables 6 and 7 about here]

\subsection{Different proxies for firm's lifecycle}

We perform a number of robustness checks. Firstly, we focus on the validity of our findings for the lifecycle by using an alternative measure. In Table 8, we use RE/TE rather than MLDA to measure lifecycle. In doing so, we establish a strong relationship between precommitment and the financial lifecycle stage of the firm. In all model specifications, the evidence is consistent with dividends becoming increasingly more important over the lifecycle. Dividends, on average, account for a higher proportion of total payout (column 4), the committed payout (column 5) and the non-debt related payout as firm progresses along the lifecycle spectrum (column 6). Increases from the preceding stage are large and statistically significant in the case of total payout and committed payout. This is consistent with firms growing and generating more revenue, and hence increasing their capacity to pay larger dividends, as they move along the lifecycle spectrum. The likelihood of a firm using a combination of dividends and debt payouts as opposed to debt (dividends) alone increases (is unchanged) (columns 7 and 8 respectively). Likewise, we observe an increasing likelihood of a firm using dividends as opposed to share repurchases alone (column 9) over the lifecycle. All three results suggest that dividends become relatively more important as a channel for cash distribution over the firm lifecycle, and hence as a precommitment mechanism. Once again, we find that interest expense to assets falls as firms mature. We find no significant relationship between share repurchase levels and the firms' lifecycle. Generally, the control variables enter with the expected sign.

[Insert Table 8 about here]

\subsection{Different emerging market - India}

In finance, the generalizability of results is key, since standalone results could be driven by market-specific characteristics. Therefore, we check if our findings are specific to Korea by repeating the analysis for Indian firms. We source corporate governance data for a sample of 238 Indian firms from Black et al. (2014) for years 2005, 2007, and 2011. Given the relatively short sample and non- 
contiguous structure of the data, we have chosen to use India as a robustness check only. In India, corporate governance is calculated as a simple weighted average of board structure, board procedure, disclosure, shareholder rights, and ownership structure. ${ }^{15}$ Relative to Korea, corporate governance standards are stronger in India; mean governance is 60.42 , with a $75^{\text {th }}$ percentile governance score of 67.44. The incidence and size of dividend payouts are larger in India (mean div/asset is $2.19 \%$ in India compared to $0.83 \%$ in Korea), and while the prevalence of debt financing is roughly the same in both countries, interest expense is larger in Korea ( $1.95 \%$ for the mean firm in India compared to $2.45 \%$ in Korea). The frequency and size of share repurchases is much lower in India compared to Korea. The proportion of firm-years with positive share repurchases is just 0.08 in India, compared to 0.43 in Korea. In India, the level of share repurchases is just $11 \%$ of the dividend amount, compared to $63 \%$ in Korea.

As payouts to capital providers in India are dominated by dividends and interest payments, we estimate the precommitment-governance relationship using div/commit only. In all specifications, lifecycle is classified using the MLDA approach. Table 9 reports our results for the full sample of firms. There is evidence to support the outcome model of dividends but not for debt, i.e. dividends as a proportion of assets increases with governance while the amount of debt and the interest expense are invariant to corporate governance. Furthermore, variation in dividends as a proportion of the sum of dividends and interest expense cannot be explained by differences in firm-level governance. Therefore, it appears that any evidence of precommitment is more consistent with the outcome model as in Korea and not the substitution model as in the U.S. Table 10 finds a similar pattern for various sub-samples of firms. ${ }^{16}$

However, and as is the case in Korea, we observe a distinct lifecycle effect, with the Div/commit ratio always being highest for mature-stage firms. The increasing use of dividends as a precommitment

\footnotetext{
${ }^{15}$ The single related party transaction element is included as part of the shareholder rights sub-index.

${ }^{16}$ While the 2SLS estimates are generally supportive of our conclusions for Korea, results from the 2SLS approach are less compelling for our Indian sample but this is due to a poor fit in the first stage of the estimation process. It suggests that the lack of consistent evidence is better associated with the poor performance of the instrument than a true conflict in the results of the different estimators. For an alternative view, we estimate firm-random effects and firm-fixed effects regressions and the story that emerges is largely consistent with results in Tables 9 and 10. The results are reported here in Appendix 2.
} 
mechanism arises due to both an increase in the dividend amount coupled with a decline in interest expense. This pattern is consistent with the results for Korea.

[Insert Tables 9 and 10 about here]

\section{Conclusion}

We analyze the relationship between payout precommitment and corporate governance and the lifecycle of firms in emerging markets using South Korea and India as a backdrop. We find little evidence of similarity in precommitment effect documented for developed markets compared to the payout behavior of Korean firms. There is no evidence that firms in emerging market substitute dividends for governance as in the U.S. Instead, precommitment through higher payouts for Korean firms is predominantly found among the better governed firms.

Our results support an outcome model of dividends and debt-related repayments for these emerging market firms, i.e. it is better-governed firms who tend to pay higher dividends to shareholders and timely loan repayments to creditors. This type of precommitment mechanism suggests that emerging market firms need to signal their commitment to the protection of external stakeholders to overcome, in the first instance, country-level institutional barriers to investment. Since all firms are contending with the same, significant country-level weakness in governance (e.g. over our sample, Korea was placed in the bottom tercile of the CIFAR - an index of accounting standard disclosures score distribution), it would appear that better governed firms are more able to commit to higher payouts. This coupled with their already superior governance differentiates them from other Korean firms. This evidence in favor of the outcome model is robust to splitting our sample into various subsamples with different characteristics, such as levels of foreign ownership, size, firm age, and any potential endogeneity concerns.

There is also strong evidence in favor of a precommitment lifecycle effect based on two different proxies for the firm lifecycle, namely the MLDA methodology (Faff et al., 2016) and a discrete version of the RE/TE variable (Owen and Yawson, 2010). Firms typically use a larger proportion of dividends in the distribution of cash to stakeholders as they progress along the lifecycle. This implies that while the typical firm employs both debt and dividends to distribute cash (and allay fears of 
managerial expropriation); it is more likely to increase the dividend proportion over its lifecycle. Precommitment becomes less important during the later stage and firms reduce the proportion of dividends relative to debt, whose obligation is likely met with the proceeds of asset sales. 


\section{References}

Aivazian, V., Booth, L., and S. Cleary. (2003). Do emerging market firms follow different dividend policies from U.S. firms? Journal of Financial Research, 26, 371-387.

Almeida, H., Kim, C., and H. Kim. (2015). Internal capital markets in business groups: evidence from the Asian financial crisis. Journal of Finance, 70, 2539-2586.

Bae, K.H., and V. Goyal. (2010). Equity market liberalization and corporate governance. Journal of Corporate Finance, 16, 609-621.

Baek, J.S., Kang, J.K., and I. Lee. (2006). Business groups and tunneling: Evidence from private securities offerings by Korean chaebols. Journal of Finance, 61, 2415-2449.

Banyi, M., and K. Kahle. (2014). Declining propensity to play? A re-examination of the lifecycle theory. Journal of Corporate Finance, 27, 345-366.

Black, B., Jang, H., and W. Kim. (2006). Predicting firms' corporate governance choices. Evidence from Korea. Journal of Corporate Finance, 12, 660-691.

Black, B., and W. Kim. (2012). The effect of board structure on firm value: a multiple identification strategies approach using Korean data. Journal of Financial Economics, 104, 203-226.

Black, B., De Carvalho, A. G., Khanna, V., Kim, W., and B. Yurtoglu. (2014). Methods for multicountry studies of corporate governance: evidence from the BRIKT countries. Journal of Econometrics, 183, 230-240.

Brav, A., Graham, J.R., Harvey, C.R., and R. Michaely. (2005). Payout policy in the $21^{\text {st }}$ century. Journal of Financial Economics, 77(3), 483-527.

Brockman, P., and E. Unlu. (2011). Earned/contributed capital, dividend policy, and disclosure quality: an international study. Journal of Banking and Finance, 35, 1610-1625.

Chang, B., Dutta, S., Saadi, S., and P. Zhu. (2018). Corporate governance and dividend payout policy: beyond country-level governance. Journal of Financial Research, 41, 445-484.

Chintrakarn, P., Chatjuthamard, P., Tong, S. and Jiraporn, P. (2018). How do powerful CEOs view dividends and stock repurchases? Evidence from the CEO pay slice (CPS). International Review of Economics and Finance, 58, 49-64.

Chay, J.B., and J. Suh. (2009). Payout policy and cash flow uncertainty. Journal of Financial Economics, 93, 88-107.

Choi, J., Park, S., and S. Yoo. (2007). The value of outside directors: evidence from corporate governance reform in Korea. Journal of Financial and Quantitative Analysis, 42, 941-962.

Coffee, J. (1999). The future as history: the prospects for global convergence in corporate governance and its implications. Northwestern University Law Review, 93, 641-708.

Coulton, J., and C. Ruddock. (2011). Corporate payout policy in Australia and a test of the life-cycle theory. Accounting and Finance, 52, 381-407. 
DeAngelo, H., DeAngelo, L., and R. Stulz. (2006). Dividend policy and the earned/contributed capital mix: a test of the life-cycle theory. Journal of Financial Economics, 81, 227-254.

Dewenter, K., Kim, C-S., Lim, U., and W. Novaes. (2005). Committing to protect investors in emerging markets: can local exchanges provide value-relevant bonding mechanisms? Working paper, University of Washington.

Denis, D., and I. Osobov (2008). Why do firms pay dividends? International evidence on the determinants of dividend policy. Journal of Financial Economics, 89, 62-82.

Dickinson, V. (2011). Cash flow patterns as a proxy for firm life-cycle. Accounting Review, 86, 19691994.

Djankov, S., McLeish, C., and A. Shleifer. (2007). Private credit in 129 countries. Journal of Financial Economics, 84, 299-329.

Doidge, C., Karolyi, G., and R. Stulz. (2007). Why do countries matter so much for corporate governance? Journal of Financial Economics, 86, pp. 1-39.

Espenlaub, S., Goyal, A. and A. Mohamed. (2019). The impact of shareholders and creditors rights on IPO performance: An international study. British Accounting Review, 52, 100872.

Faff, R., Kwok, W., Podolski, E., and G. Wong. (2016). Do corporate policies follow a life cycle? Journal of Banking and Finance, 69, 95-107.

Fama, E., and K. French. (2001). Disappearing dividends: Changing characteristics or lower propensity to pay? Journal of Financial Economics, 60, 3-43.

Fan, J., Titman, S., and G. Twite. (2012). An international comparison of capital structure and debt maturity choices. Journal of Financial and Quantitative Analysis, 47, 23-56.

Flavin, T., and T. O'Connor. (2017). Reputation building and the life-cycle model of dividends. Pacific Basin Finance Journal, 46, 177-190.

Gompers, P., Ishii, J., and A. Metrick. (2003). Corporate governance and equity prices. The Quarterly Journal of Economics, 107-155.

Goodell, J.W. and A. Goyal. (2018). What determines debt structure in emerging markets: Transaction costs or public monitoring? International Review of Financial Analysis, 55, 184-195.

Goyal, A., and C. Muckley. (2013). Cash dividends and investor protection in Asia. International Review of Financial Analysis, 29, 31-43.

Goyal, A., Jategaonkar, S.P. and C.B. Muckley, (2020). Why do privatized firms pay higher dividends? Journal of Corporate Finance, 60, 101493.

Harvey, C., Lins, K., and A. Roper. (2004). The effect of capital structure when expected agency costs are extreme. Journal of Financial Economics, 74, 3-30.

Hovakimian, A., Opler, T., and S. Titman. (2001). The debt-equity choice. Journal of Financial and Quantitative Analysis, 36, 1-24.

Hwang, L.S., Kim, H., Park, K., and Park, R.S. (2013). Corporate governance and payout policy: Evidence from Korean business groups. Pacific-Basin Finance Journal, 24, 179-198. 
Jensen, M.C., and W.H. Meckling. (1976). Theory of the firm: Managerial behavior, agency costs and ownership structure. Journal of Financial Economics, 3, 305-360.

Jeon, J., Lee, C., and C. Moffett. (2011). Effects of foreign ownership on payout policy: evidence from the Korean market. Journal of Financial Markets, 14, 344-375.

Jiraporn, P., and K. Gleason. (2007). Capital structure, shareholder rights, and corporate governance. Journal of Financial Research, 30, 21-33.

Jiraporn, P., Kim, J.C., and Y.S. Kim. (2011). Dividend payouts and corporate governance quality: an empirical investigation. The Financial Review, 46, 251-279.

John, K., Knyazeva, A., and D. Knyazeva. (2015). Governance and payout precommitment. Journal of Corporate Finance, 33, 101-117.

Karolyi, G. (2012). Corporate governance, agency problems and international cross-listings: a defense of the bonding hypothesis. Emerging Markets Review, 13 (4), 516-547.

Kieschnick, K., and R. Moussawi. (2018). Firm age, corporate governance, and capital structure choices. Journal of Corporate Finance, 48, 597-614.

Kim, H. (2015). Debt, maturity, and corporate governance: evidence from Korea. Emerging Markets Finance and Trade, 51, 3-19.

Knyazeva, A., and D. Knyazeva. (2014). Dividend smoothing: An agency explanation and new evidence. Working paper, available at SSRN https://ssrn.com/abstract=2504715.

La Porta, R., Lopez-de-Silanes, F., Shleifer, A., and R. Vishny. (1997). Legal determinants of external finance, Journal of Finance, 52, 1131-1150.

La Porta, R., Lopez-de-Silanes, F., and A. Shleifer. (1999). Corporate ownership around the world. Journal of Finance, 54, 471-517.

La Porta, R., Lopez-de-Silanes, F., Shleifer, A., and R. Vishny. (2000). Agency problems and dividend policy around the world. Journal of Finance, 55, 1-33.

Licht, A. (2004). Legal plug-ins: cultural distance, cross-listing, and corporate governance reform. Berkeley Journal of International Law, 22, 195-239.

Lozano, M., Lopez-Iturriaga, F., and V. Braz-Bezzera. (2019). Regulatory dualism as an alternative trust enhancing mechanism for dividends and debt: Evidence from Brazil. International Review of Finance, forthcoming.

Mitton, T. (2002). A cross-firm analysis of the impact of corporate governance on the East Asian financial crisis. Journal of Financial Economics, 64, 215-241.

Mitton, T. (2004). Corporate governance dividend policy in emerging markets. Emerging Markets Review, 5, 409-426.

Myers, S. (2000). Outside equity. Journal of Finance, 55, 1005-1037.

Owen, S., and A. Yawson. (2010). Corporate life cycle and M\&A activity. Journal of Banking and Finance, 34, 427-440. 
Ribstein, L. (2005). Cross-listing and regulatory competition. Review of Law and Economics, 1, 97148.

Sarkissian, S., and M. Schill. (2003). The overseas listing decision: new evidence of proximity preference. The Review of Financial Studies, 17, 769-809.

Stepanyan, G. (2011). Firm life cycle and the choice of the form of payout. Working paper, IESEG School of Management (LEM-CNRS).

Sundaresan, S., Wang, N., and J. Wang. (2015). Dynamic investment, capital structure, and debt overhang. Review of Corporate Finance Studies, 4, 1-42.

Von Eije, H., and W.H. Megginson. (2008). Dividends and share repurchases in the European Union. Journal of Financial Economics, 89, 347-374.

Welch, I. (2011). Two common problems in capital structure research: the financing-debt-to-asset ratio and issuing activity versus leverage changes. International Review of Finance, 11, 1-17. 


\begin{tabular}{|c|c|c|c|c|c|}
\hline Variable & Description & Source & Mean & Median & Std. D \\
\hline Div/Assets (\%) & $\begin{array}{l}\text { Common dividends to book assets. Dividends is total cash dividends paid to common } \\
\text { shareholders, including extra and special dividends }\end{array}$ & Worldscope & 0.83 & 0.62 & 0.80 \\
\hline SR/Assets $(\%)$ & Share repurchases to book assets & Worldscope & 0.52 & 0.00 & 1.44 \\
\hline Int/Assets (\%) & Interest expense to book assets & Worldscope & 2.45 & 1.90 & 2.13 \\
\hline Div/Total & The ratio of common dividends to the sum of cash dividends, share repurchases and interest & Worldscope & 0.29 & 0.22 & 0.27 \\
\hline Div/Commit & The ratio of common dividends to the sum of cash dividends and interest & Worldscope & 0.33 & 0.25 & 0.30 \\
\hline Div/Payout & The ratio of common dividends to the sum of cash dividends and share repurchases & Worldscope & 0.76 & 1.00 & 0.35 \\
\hline Commitment type 1 & Equals 1 if the firm uses dividends and debt and 0 if the firm uses debt only & Worldscope & 0.93 & 1.00 & 0.26 \\
\hline Commitment type 2 & Equals 1 if the firm uses dividends and debt and 0 if the firm uses dividends only & Worldscope & 0.95 & 1.00 & 0.21 \\
\hline Payout type & Equals 1 if the firm pays a dividend and 0 if the firm repurchases only & Worldscope & 0.93 & 1.00 & 0.25 \\
\hline Corporate governance & Korea corporate governance index (KCGI) from Black et al. (2014) & Black et al. (2014) & 35.82 & 34.08 & 11.64 \\
\hline $\mathrm{RE} / \mathrm{TE}$ & Retained equity to total equity & Worldscope & 0.45 & 0.43 & 0.33 \\
\hline RE/TA & Retained equity to book assets & Worldscope & 0.23 & 0.19 & 0.17 \\
\hline TE/TA & Total equity to book assets & Worldscope & 0.49 & 0.48 & 0.19 \\
\hline Cash holdings & Cash to book assets & Worldscope & 0.12 & 0.09 & 0.10 \\
\hline Leverage & Total liabilities to book assets & Worldscope & 0.49 & 0.50 & 0.18 \\
\hline Investment opportunities & Market to book value of assets & Worldscope & 0.64 & 0.47 & 0.58 \\
\hline Firm size & Log of firm market value in millions of US\$ & Worldscope & 4.44 & 4.13 & 1.53 \\
\hline Size dummy & Equals 1 if book value of assets $>2$ trillion won; zero otherwise & Worldscope & 0.13 & 0.00 & 0.33 \\
\hline Tangibility & Ratio of property plant and equipment to book assets & Worldscope & 0.41 & 0.41 & 0.16 \\
\hline Cash flow uncertainty & Standard deviation of (operating income/total assets) over the most recent four years & Worldscope & 0.04 & 0.03 & 0.05 \\
\hline Chaebol & Equals one if the firm belongs to a Chaebol business group; zero otherwise & Black et al. (2014) & 0.39 & 0.00 & 0.49 \\
\hline Book debt & Total debt to book assets & Worldscope & 0.26 & 0.27 & 0.17 \\
\hline Financial debt to capital & $\begin{array}{l}\text { Financial debt to capital, where capital is the sum of interest-bearing debt and shareholders' } \\
\text { equity }\end{array}$ & Worldscope & 0.36 & 0.36 & 0.23 \\
\hline MLDA lifecycle & $\begin{array}{l}\text { MLDA lifecycle indicator. There are four lifecycle stages, namely birth-stage, growth-stage, } \\
\text { mature-stage, shake-out/decline stage. Firms are assigned to a lifecycle stage based on Dickenson } \\
\text { (2011) and multivariate linear discriminant analysis using firm age, RE/TA, profitability, and } \\
\text { asset growth }\end{array}$ & Worldscope & n.m. & n.m. & n.m. \\
\hline Firm age & Age of firm: year less establishment year plus 1 & Black et al. (2014) & 35.88 & 35.00 & 13.69 \\
\hline Profitability & Earnings before interest and taxation to book assets & Worldscope & 0.04 & 0.03 & 0.05 \\
\hline Asset growth & One-year asset growth & Worldscope & 0.06 & 0.04 & 0.23 \\
\hline Foreign ownership & $\%$ shares held by foreign shareholders & Black et al. (2014) & 0.12 & 0.04 & 0.16 \\
\hline CAPEX & Ratio of capital expenditures (CAPEX) to book assets & Worldscope & 0.05 & 0.04 & 0.05 \\
\hline External financing need & (CAPEX-Cash flow from operations)/CAPEX & Worldscope & $(1.62)$ & $(0.48)$ & 10.66 \\
\hline
\end{tabular}




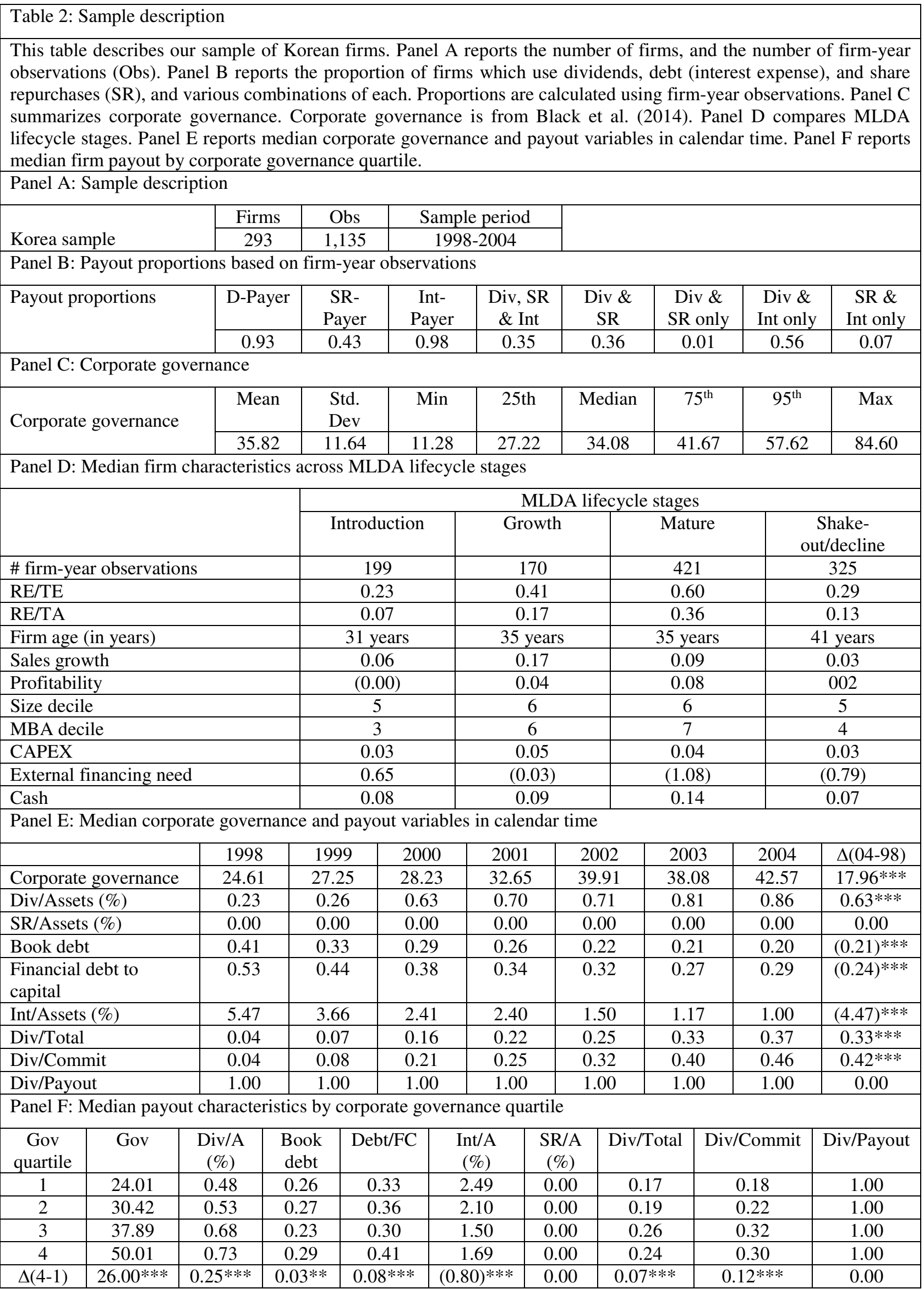




\begin{tabular}{|c|c|c|c|c|c|}
\hline \multirow{2}{*}{\multicolumn{6}{|c|}{$\begin{array}{l}\text { This table reports pooled ordinary least squares estimates for a sample of } 293 \text { firms from Korea. Test-statistics, calculated using } \\
\text { standard errors clustered by firm are underneath each estimated coefficient in parentheses. The sample period is } 1998 \text { to } 2004 . \text { The } \\
\text { dependent variable is dividends to assets (\%), interest expense to assets (\%), book debt, financial debt to capital and share repurchases } \\
\text { to assets }(\%) \text {, as indicated. Lifecycle is proxied using MLDA. We define all variables in Table } 1 \text {. Though unreported, all regressions } \\
\text { include an intercept term, industry, and time dummies. ***, **, and *, denotes statistical significance at the } 1,5 \text {, and } 10 \% \text { levels, } \\
\text { respectively. }\end{array}$}} \\
\hline & & & & & \\
\hline & 1 & 2 & 3 & 4 & 5 \\
\hline & $\begin{array}{c}\text { Div/Assets } \\
(\%)\end{array}$ & Book debt & $\begin{array}{c}\text { Financial debt to } \\
\text { capital }\end{array}$ & $\begin{array}{c}\text { Int/Assets } \\
(\%)\end{array}$ & $\begin{array}{c}\text { SR/Assets } \\
(\%)\end{array}$ \\
\hline Corporate governance & $\begin{array}{c}0.011^{* * * *} \\
(2.55)\end{array}$ & $\begin{array}{c}0.002 * * \\
(2.23)\end{array}$ & $\begin{array}{c}0.003 * * * \\
(2.66)\end{array}$ & $\begin{array}{c}0.016^{*} \\
(1.89)\end{array}$ & $\begin{array}{l}0.018 \\
(1.25)\end{array}$ \\
\hline TE/TA & $\begin{array}{l}0.536 \\
(0.91)\end{array}$ & & & & $\begin{array}{r}-0.910 \\
(0.78)\end{array}$ \\
\hline Growth-stage & $\begin{array}{l}0.027 \\
(0.47)\end{array}$ & $\begin{array}{c}-0.083^{* * * *} \\
(4.84)\end{array}$ & $\begin{array}{c}-0.081 * * * \\
(3.71)\end{array}$ & $\begin{array}{c}-1.142 * * * \\
(6.03)\end{array}$ & $\begin{array}{l}0.142 \\
(1.11)\end{array}$ \\
\hline Mature-stage & $\begin{array}{c}0.188 * * \\
(2.49)\end{array}$ & $\begin{array}{c}-0.168 * * * \\
(9.06)\end{array}$ & $\begin{array}{c}-0.231 * * * \\
(9.94)\end{array}$ & $\begin{array}{c}-1.213 * * * \\
(6.22)\end{array}$ & $\begin{array}{l}0.154 \\
(1.16)\end{array}$ \\
\hline Shake-out/decline-stage & $\begin{array}{l}0.059 \\
(1.09)\end{array}$ & $\begin{array}{c}-0.062 * * * \\
(4.14)\end{array}$ & $\begin{array}{c}-0.086^{* * * *} \\
(4.78)\end{array}$ & $\begin{array}{c}-0.172 \\
(1.03)\end{array}$ & $\begin{array}{l}-0.101 \\
(0.95)\end{array}$ \\
\hline Investment opportunities & $\begin{array}{c}0.355 * * * \\
(5.08)\end{array}$ & $\begin{array}{c}-0.012 \\
(0.96)\end{array}$ & $\begin{array}{c}-0.010 \\
(0.57)\end{array}$ & $\begin{array}{c}-0.278 * * \\
(2.02)\end{array}$ & $\begin{array}{c}0.233 * \\
(1.70)\end{array}$ \\
\hline Firm size & $\begin{array}{c}-0.020 \\
(0.56)\end{array}$ & $\begin{array}{l}-0.003 \\
(0.33)\end{array}$ & $\begin{array}{l}-0.007 \\
(0.73)\end{array}$ & $\begin{array}{l}-0.060 \\
(0.84)\end{array}$ & $\begin{array}{l}0.129 * \\
(1.91)\end{array}$ \\
\hline Size dummy & $\begin{array}{c}-0.210 * \\
(1.95)\end{array}$ & $\begin{array}{l}0.041^{*} \\
(1.96)\end{array}$ & $\begin{array}{c}0.081^{* *} \\
(2.52)\end{array}$ & $\begin{array}{l}0.440 * * \\
(2.04)\end{array}$ & $\begin{array}{l}-0.554 \\
(1.41)\end{array}$ \\
\hline Asset tangibility & $\begin{array}{c}-0.481 * * \\
(2.27)\end{array}$ & $\begin{array}{l}0.047 \\
(0.90)\end{array}$ & $\begin{array}{l}-0.054 \\
(0.82)\end{array}$ & $\begin{array}{l}-0.288 \\
(0.48)\end{array}$ & $\begin{array}{l}-0.595 \\
(1.47)\end{array}$ \\
\hline Cash flow uncertainty & $\begin{array}{c}-0.762 * \\
(1.81)\end{array}$ & $\begin{array}{l}0.006 \\
(0.07)\end{array}$ & $\begin{array}{l}0.021 \\
(0.21)\end{array}$ & $\begin{array}{c}2.499 * * \\
(2.53)\end{array}$ & $\begin{array}{l}-0.376 \\
(0.60)\end{array}$ \\
\hline Leverage & $\begin{array}{c}-1.144^{*} \\
(1.85)\end{array}$ & & & & $\begin{array}{l}-1.306 \\
(1.14)\end{array}$ \\
\hline Cash & -0.161 & $-0.338 * * *$ & $-0.525 * * *$ & $-3.998 * * *$ & -0.401 \\
\hline \multirow[t]{2}{*}{ Chaebol } & $\begin{array}{l}(0.53) \\
-0.035\end{array}$ & $0.045 * *$ & $\begin{array}{c}(6.35) \\
0.089 * * *\end{array}$ & $\begin{array}{l}(0.81) \\
0.425^{*} *\end{array}$ & $\begin{array}{r}(0.49) \\
-0.059\end{array}$ \\
\hline & $(0.43)$ & $(2.32)$ & $(3.34)$ & $(2.09)$ & $(0.42)$ \\
\hline \multirow{5}{*}{$\begin{array}{l}\text { Time dummies } \\
\text { Industry dummies } \\
\text { Observations } \\
\text { R-squared } \\
\end{array}$} & Yes & Yes & Yes & Yes & Yes \\
\hline & Yes & Yes & Yes & Yes & Yes \\
\hline & 1,135 & 1,135 & 1,135 & 1,135 & 1,135 \\
\hline & 0.363 & 0.467 & 0.505 & 0.556 & 0.093 \\
\hline & \multicolumn{5}{|c|}{ Tests for differences across MLDA lifecycle stages } \\
\hline Mature vs. growth & $* * *$ & $* * *$ & $* * *$ & & \\
\hline Mature vs. so/decline & $* *$ & $* * *$ & $* * *$ & $* * *$ & $*$ \\
\hline Growth vs. so/decline & & & & $* * *$ & $*$ \\
\hline
\end{tabular}




\begin{tabular}{|c|c|c|c|c|c|c|}
\hline \multicolumn{7}{|c|}{$\begin{array}{l}\text { This table reports pooled ordinary least squares estimates for a sample of } 293 \text { firms from Korea. The sample period is } \\
1998 \text { to } 2004 \text {. Test-statistics, calculated using standard errors clustered by firm are underneath each estimated } \\
\text { coefficient in parentheses. The dependent variable is Div/Total, Div/Commit, and Div/Payout, Commitment type } 1 \\
\text { (Div \& Debt vs. Debt only), Commitment type } 2 \text { (Div \& Debt vs. Dividend only), and Payout type (Dividends vs. } \\
\text { Repurchase only), as indicated. We measure firm lifecycle using MLDA. We define all variables in Table } 1 \text {. Though } \\
\text { unreported, all regressions include an intercept term, industry, and time dummies. ***, **, and *, denotes statistical } \\
\text { significance at the } 1,5 \text {, and } 10 \% \text { levels, respectively. }\end{array}$} \\
\hline & \multicolumn{6}{|c|}{ Dependent variable is } \\
\hline & 1 & 2 & 3 & 4 & 5 & 6 \\
\hline & Div/Total & Div/Comm & Div/Payout & $\begin{array}{l}\text { Commitmen } \\
\text { t type 1: } \\
\text { Div \& Debt } \\
\text { vs. Debt } \\
\text { only } \\
\end{array}$ & $\begin{array}{l}\text { Commitment } \\
\text { type } 2: \\
\text { Div \& Debt } \\
\text { vs. Dividend } \\
\text { only }\end{array}$ & $\begin{array}{l}\text { Dividend } \\
\text { vs. Rep } \\
\text { only }\end{array}$ \\
\hline Corporate governance & $\begin{array}{l}-0.001 \\
(0.36)\end{array}$ & $\begin{array}{l}0.001 \\
(1.16)\end{array}$ & $\begin{array}{l}-0.002 \\
(0.89)\end{array}$ & $\begin{array}{l}0.002 \\
(1.18)\end{array}$ & $\begin{array}{l}-0.001 \\
(1.32)\end{array}$ & $\begin{array}{l}0.002 \\
(1.20)\end{array}$ \\
\hline Growth-stage & $\begin{array}{c}0.037^{*} \\
(1.89)\end{array}$ & $\begin{array}{c}0.043^{* *} * \\
(2.14)\end{array}$ & $\begin{array}{l}0.018 \\
(0.42)\end{array}$ & $\begin{array}{c}0.091 * * \\
(2.57)\end{array}$ & $\begin{array}{l}0.022 \\
(0.93)\end{array}$ & $\begin{array}{c}0.087 * * \\
(2.54)\end{array}$ \\
\hline Mature-stage & $\begin{array}{c}0.049 * * \\
(2.17)\end{array}$ & $\begin{array}{c}0.061 * * \\
(2.43)\end{array}$ & $\begin{array}{l}0.004 \\
(0.10)\end{array}$ & $\begin{array}{c}0.061^{*} \\
(1.82)\end{array}$ & $\begin{array}{l}0.040 \\
(1.12)\end{array}$ & $\begin{array}{c}0.055^{*} \\
(1.76)\end{array}$ \\
\hline Shake-out/decline-stage & $\begin{array}{r}-0.011 \\
(0.70)\end{array}$ & $\begin{array}{l}-0.025 \\
(1.50)\end{array}$ & $\begin{array}{c}0.088 * * \\
(2.40)\end{array}$ & $\begin{array}{c}0.067 * * \\
(2.26)\end{array}$ & $\begin{array}{c}0.036^{*} \\
(1.81)\end{array}$ & $\begin{array}{c}0.065^{* *} \\
(2.23)\end{array}$ \\
\hline $\mathrm{TE} / \mathrm{TA}$ & $\begin{array}{c}0.719 * * * \\
(11.93)\end{array}$ & $\begin{array}{c}0.833 * * * \\
(12.94)\end{array}$ & $\begin{array}{c}0.306 * * * \\
(3.77)\end{array}$ & $\begin{array}{c}0.216^{* * * *} \\
(3.51)\end{array}$ & $\begin{array}{c}-0.308 * * * \\
(3.81)\end{array}$ & $\begin{array}{c}0.223 * * * \\
(3.90)\end{array}$ \\
\hline Investment opportunities & $\begin{array}{c}0.051 * * * \\
(3.08)\end{array}$ & $\begin{array}{c}0.082 * * * \\
(3.82)\end{array}$ & $\begin{array}{l}0.006 \\
(0.18)\end{array}$ & $\begin{array}{c}-0.020 \\
(1.05)\end{array}$ & $\begin{array}{c}-0.033 \\
(1.57)\end{array}$ & $\begin{array}{r}-0.016 \\
(0.91)\end{array}$ \\
\hline Firm size & $\begin{array}{r}-0.011 \\
(1.23)\end{array}$ & $\begin{array}{c}-0.002 \\
(0.22)\end{array}$ & $\begin{array}{c}-0.029 * \\
(1.94)\end{array}$ & $\begin{array}{l}0.011 \\
(1.03)\end{array}$ & $\begin{array}{l}0.010 \\
(0.88)\end{array}$ & $\begin{array}{l}0.011 \\
(1.05)\end{array}$ \\
\hline Size dummy & $\begin{array}{l}0.013 \\
(0.56)\end{array}$ & $\begin{array}{c}-0.022 \\
(0.81)\end{array}$ & $\begin{array}{c}-0.003 \\
(0.06)\end{array}$ & $\begin{array}{c}-0.077 * \\
(1.71)\end{array}$ & $\begin{array}{l}-0.005 \\
(0.23)\end{array}$ & $\begin{array}{c}-0.078 * \\
(1.75)\end{array}$ \\
\hline Asset tangibility & $\begin{array}{c}-0.087 * \\
(1.69)\end{array}$ & $\begin{array}{c}-0.128 * * \\
(2.22)\end{array}$ & $\begin{array}{l}-0.020 \\
(0.22)\end{array}$ & $\begin{array}{c}-0.100 \\
(1.54)\end{array}$ & $\begin{array}{l}0.020 \\
(0.36)\end{array}$ & $\begin{array}{r}-0.101 \\
(1.63)\end{array}$ \\
\hline Cash flow uncertainty & $\begin{array}{r}-0.161 \\
(0.86)\end{array}$ & $\begin{array}{c}-0.292 \\
(1.41)\end{array}$ & $\begin{array}{c}-0.705^{* *} \\
(2.20)\end{array}$ & $\begin{array}{c}-1.065^{* * * *} \\
(3.25)\end{array}$ & $\begin{array}{c}-0.018 \\
(0.13)\end{array}$ & $\begin{array}{c}-1.036 * * * \\
(3.32)\end{array}$ \\
\hline Cash & $\begin{array}{c}0.250 * * \\
(2.17)\end{array}$ & $\begin{array}{c}0.259 * * \\
(2.12)\end{array}$ & $\begin{array}{l}-0.011 \\
(0.09)\end{array}$ & $\begin{array}{l}-0.085 \\
(0.88)\end{array}$ & $\begin{array}{c}-0.426 * * \\
(2.38)\end{array}$ & $\begin{array}{l}-0.076 \\
(0.94)\end{array}$ \\
\hline Chaebol & $\begin{array}{l}0.008 \\
(0.38) \\
\end{array}$ & $\begin{array}{r}-0.003 \\
(0.11) \\
\end{array}$ & $\begin{array}{l}0.035 \\
(0.99) \\
\end{array}$ & $\begin{array}{r}-0.019 \\
(0.76) \\
\end{array}$ & $\begin{array}{c}-0.030 \\
(1.48)\end{array}$ & $\begin{array}{c}-0.018 \\
(0.72)\end{array}$ \\
\hline $\begin{array}{l}\text { Time dummies } \\
\text { Industry dummies } \\
\text { Observations } \\
\text { R-squared }\end{array}$ & $\begin{array}{l}\text { Yes } \\
\text { Yes } \\
1,135 \\
0.531\end{array}$ & $\begin{array}{l}\text { Yes } \\
\text { Yes } \\
1,135 \\
0.393\end{array}$ & $\begin{array}{l}\text { Yes } \\
\text { Yes } \\
1,135 \\
0.085\end{array}$ & $\begin{array}{c}\text { Yes } \\
\text { Yes } \\
1,086 \\
0.112\end{array}$ & $\begin{array}{c}\text { Yes } \\
\text { Yes } \\
1,057 \\
0.113\end{array}$ & $\begin{array}{c}\text { Yes } \\
\text { Yes } \\
1,135 \\
0.113\end{array}$ \\
\hline & \multicolumn{6}{|c|}{ Tests for differences in payout precommitment across MLDA lifecycle stages } \\
\hline $\begin{array}{l}\text { Mature vs. growth } \\
\text { Mature vs. so/decline } \\
\text { Growth vs. so/decline }\end{array}$ & $\begin{array}{l}* * * \\
* * *\end{array}$ & $\begin{array}{l}* * * \\
* * *\end{array}$ & $\begin{array}{l}* * \\
* * *\end{array}$ & & & \\
\hline
\end{tabular}




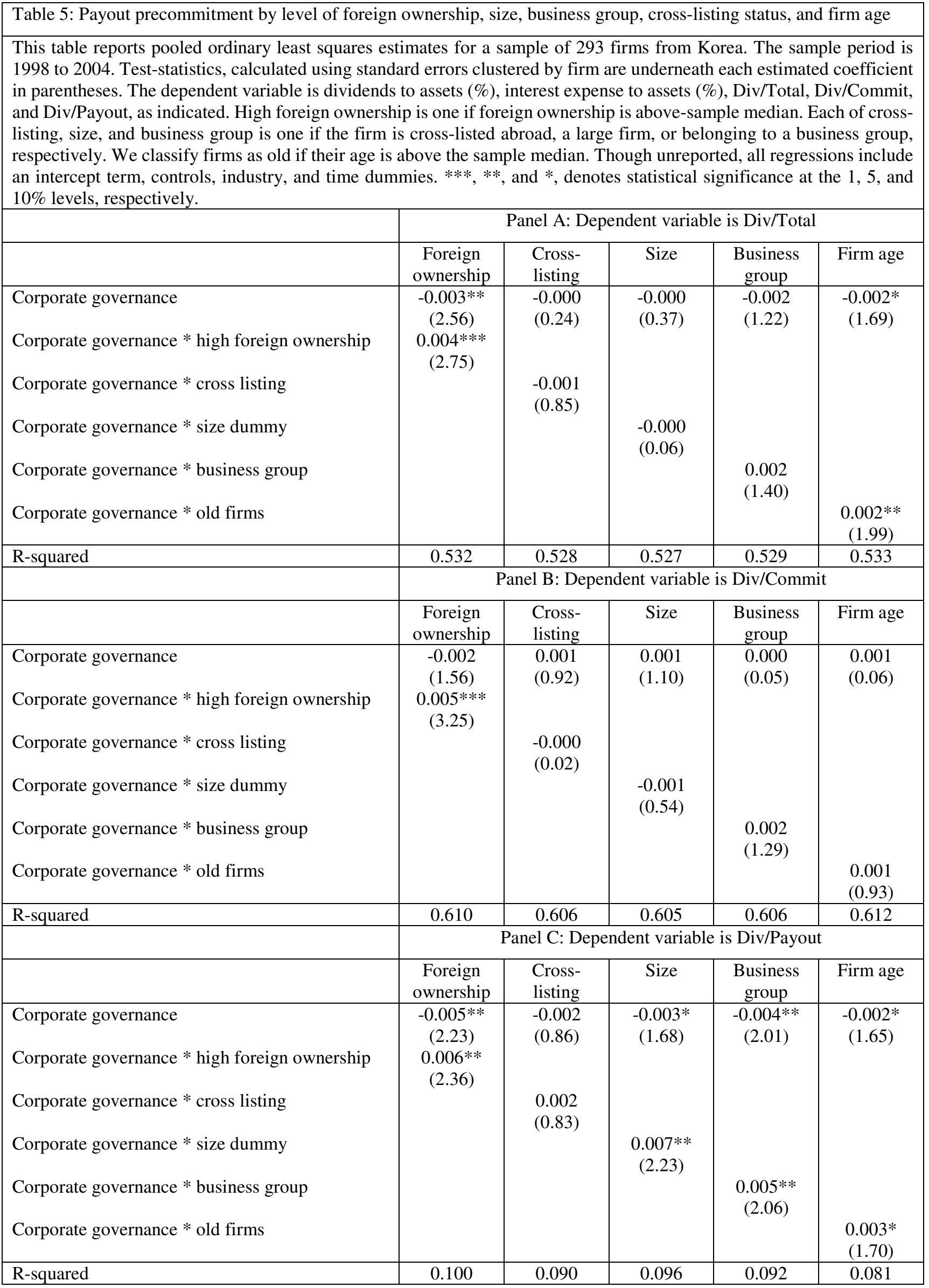


Table 5: Payout precommitment by level of foreign ownership, size, business group, cross-listing status, and firm age

This table reports pooled ordinary least squares estimates for a sample of 293 firms from Korea. The sample period is 1998 to 2004. Test-statistics, calculated using standard errors clustered by firm are underneath each estimated coefficient in parentheses. The dependent variable is dividends to assets (\%), interest expense to assets (\%), Div/Total, Div/Commit, and Div/Payout, as indicated. High foreign ownership is one if foreign ownership is above-sample median. Each of crosslisting, size, and business group is one if the firm is cross-listed abroad, a large firm, or belonging to a business group, respectively. We classify firms as old if their age is above the sample median. Though unreported, all regressions include an intercept term, controls, industry, and time dummies. ***, **, and *, denotes statistical significance at the 1,5 , and $10 \%$ levels, respectively.

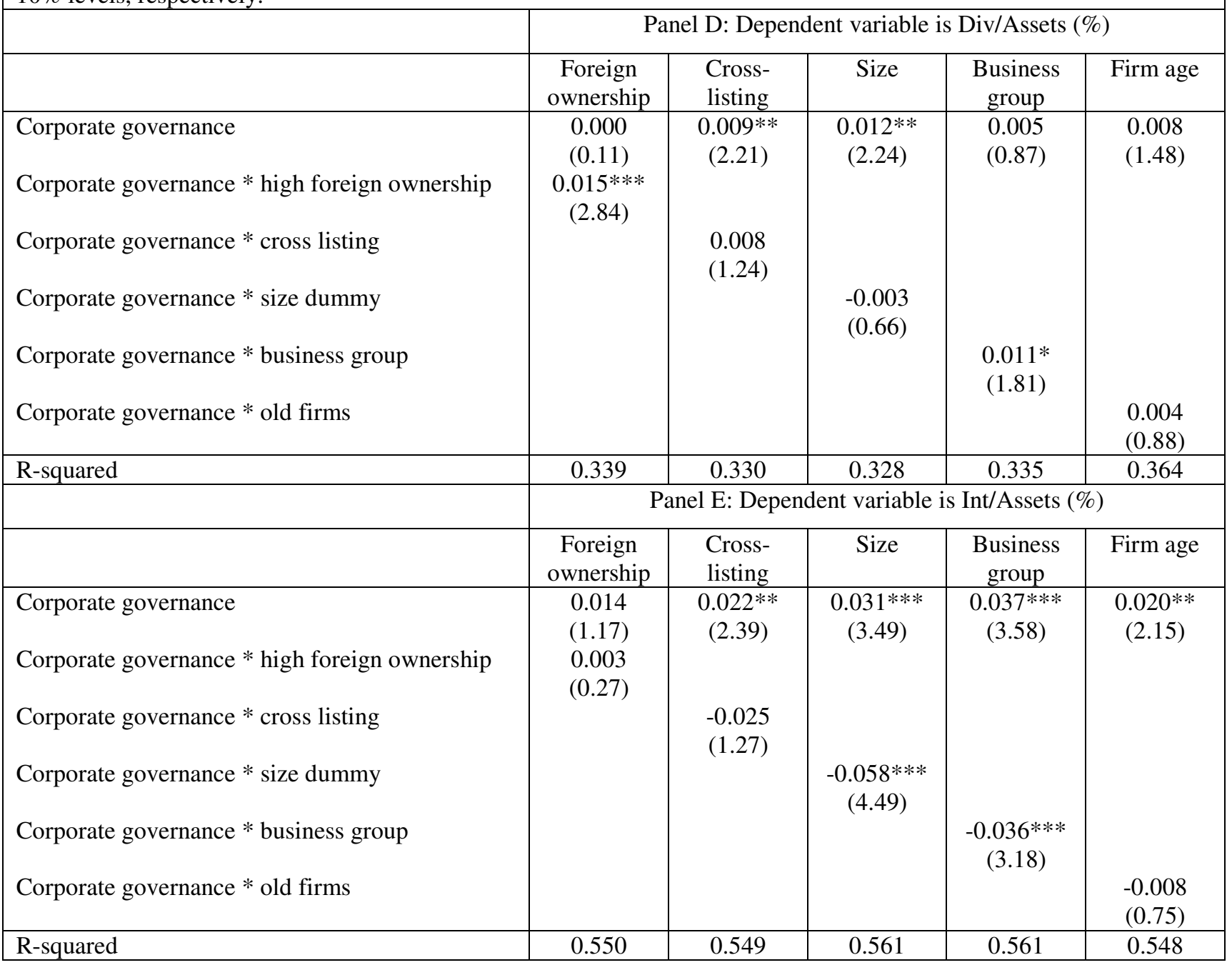


Table 6: Payouts to shareholders and creditors, payout precommitment and corporate governance: two-stage least squares estimates

This table reports coefficient estimates from pooled ordinary least squares (POLS) and second-stage two stage least squares (2SLS) regressions for a sample of 293 firms from Korea. Test-statistics, calculated using standard errors clustered by firm are underneath each estimated coefficient in parentheses. The sample period is 1998 to 2004 . The dependent variable is dividends to assets (\%) [Div/Assets], book debt, financial debt to capital, interest expense to assets [Int/Assets] and share repurchases to assets (\%), as indicated. Lifecycle is proxied using MLDA (unreported). We define all variables in Table 1. Though unreported, all regressions include an intercept term, firm-level controls, industry, and time dummies. ***, **, and *, denotes statistical significance at the 1,5 , and $10 \%$ levels, respectively.

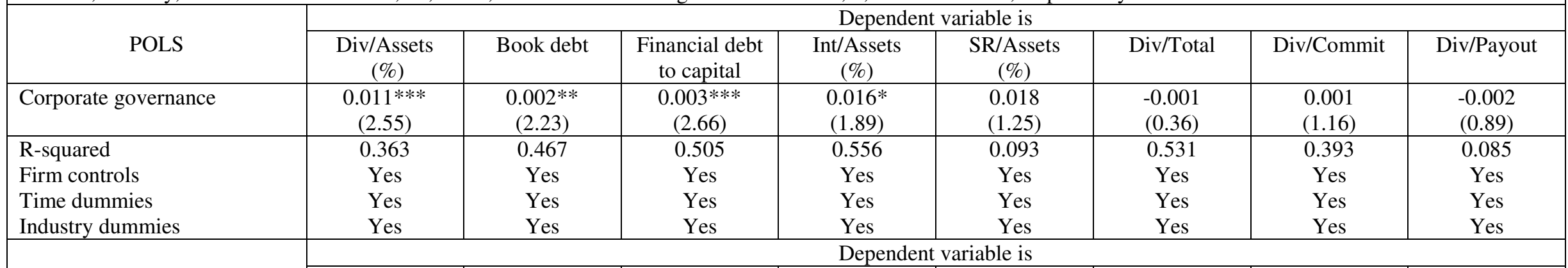

\begin{tabular}{|c|c|c|c|c|c|c|c|c|}
\hline \multirow[b]{2}{*}{ 2SLS } & \multicolumn{8}{|c|}{ 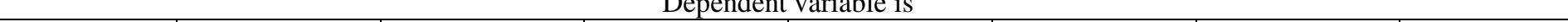 } \\
\hline & $\begin{array}{c}\text { Div/Assets } \\
(\%)\end{array}$ & Book debt & $\begin{array}{c}\text { Financial debt } \\
\text { to capital }\end{array}$ & $\begin{array}{c}\text { Int/Assets } \\
(\%)\end{array}$ & $\begin{array}{c}\text { SR/Assets } \\
(\%)\end{array}$ & Div/Total & Div/Commit & Div/Payout \\
\hline Fitted corporate governance & $\begin{array}{l}0.018 \\
(0.51) \\
\end{array}$ & $\begin{array}{l}-0.002 \\
(0.19) \\
\end{array}$ & $\begin{array}{l}-0.004 \\
(0.73) \\
\end{array}$ & $\begin{array}{l}-0.100 \\
(0.50) \\
\end{array}$ & $\begin{array}{l}0.000 \\
(0.04) \\
\end{array}$ & $\begin{array}{l}0.003 \\
(0.16) \\
\end{array}$ & $\begin{array}{l}0.001 \\
(0.13) \\
\end{array}$ & $\begin{array}{l}0.001 \\
(0.10) \\
\end{array}$ \\
\hline R-squared & 0.346 & 0.689 & 0.874 & 0.649 & 0.064 & 0.527 & 0.602 & 0.075 \\
\hline Firm controls & Yes & Yes & Yes & Yes & Yes & Yes & Yes & Yes \\
\hline Time dummies & Yes & Yes & Yes & Yes & Yes & Yes & Yes & Yes \\
\hline Industry dummies & Yes & Yes & Yes & Yes & Yes & Yes & Yes & Yes \\
\hline \multicolumn{8}{|c|}{ Industry median governance from first stage 2 SLS regression } & $\begin{array}{c}0.548 * * * \\
(3.72)\end{array}$ \\
\hline \multicolumn{8}{|c|}{ R-squared from first stage 2 SLS regression } & 0.646 \\
\hline \multicolumn{8}{|c|}{ F-test instruments from first stage 2SLS regression } & $30.38 * * *$ \\
\hline
\end{tabular}




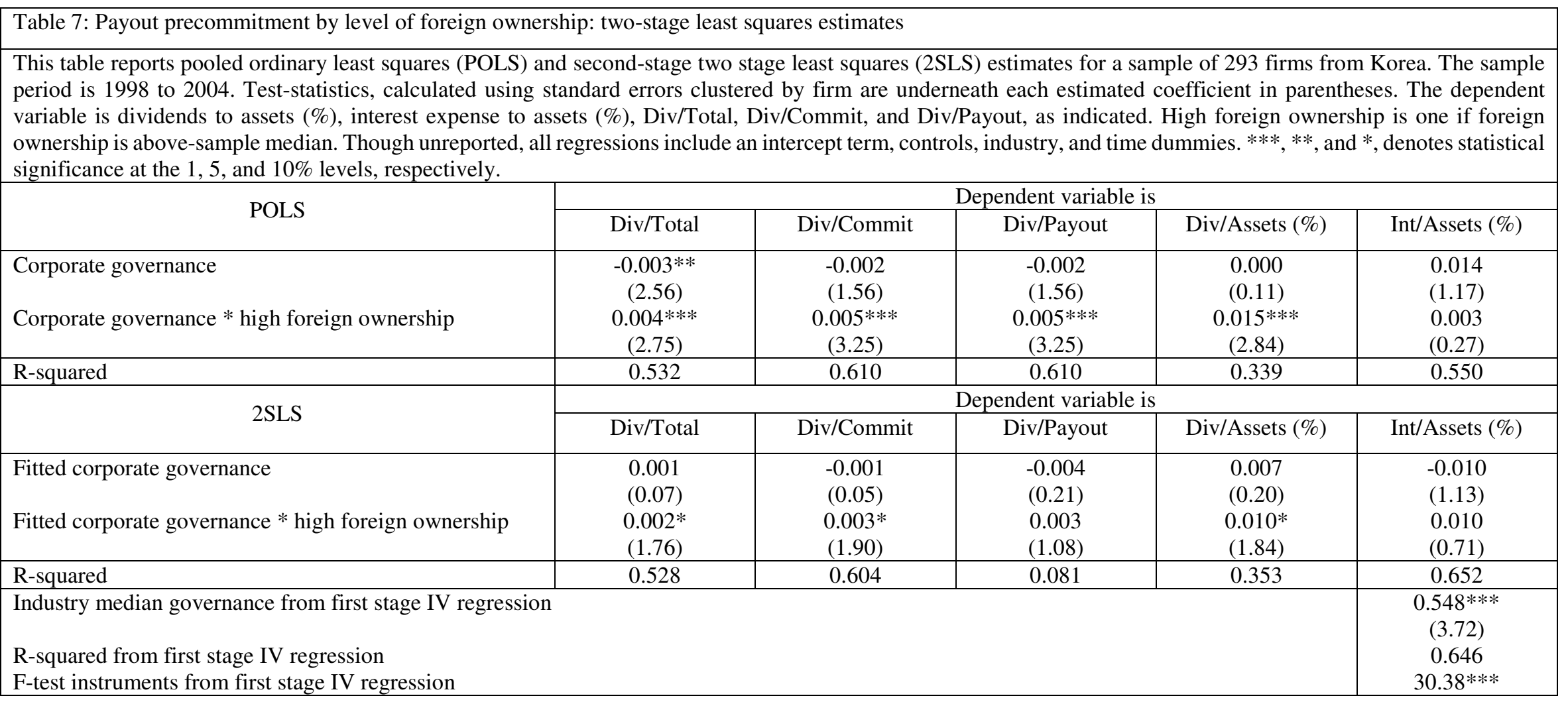




\begin{tabular}{|c|c|c|c|c|c|c|c|c|c|}
\hline \multicolumn{10}{|c|}{$\begin{array}{l}\text { This table reports pooled ordinary least squares estimates for a sample of } 293 \text { firms from South Korea. The sample period is } 1998 \text { to } 2004 \text {. Test-statistics, calculated using } \\
\text { standard errors clustered by firm are underneath each estimated coefficient in parentheses. Firm lifecycle stages are measured using RE/TE lifecycle. We define all variables } \\
\text { in Table } 1 \text {. Though unreported, all regressions include an intercept term, industry, and time dummies. ***, **, and *, denotes statistical significance at the } 1,5 \text {, and } 10 \% \\
\text { levels, respectively. }\end{array}$} \\
\hline & \multicolumn{9}{|c|}{ Dependent variable is } \\
\hline & 1 & 2 & 3 & 4 & 5 & 6 & 7 & 8 & 9 \\
\hline & $\begin{array}{c}\text { Div/Assets } \\
(\%)\end{array}$ & $\begin{array}{c}\text { Int/Assets } \\
(\%)\end{array}$ & $\begin{array}{c}\text { SR/Assets } \\
(\%)\end{array}$ & Div/Total & Div/Commit & Div/Payout & $\begin{array}{l}\text { Commitment } \\
\text { type } 1\end{array}$ & $\begin{array}{l}\text { Commitment } \\
\text { type } 2\end{array}$ & $\begin{array}{l}\text { Dividend vs. } \\
\text { Repurchase } \\
\text { only }\end{array}$ \\
\hline Corporate governance & $\begin{array}{c}0.012 * * * \\
(2.79)\end{array}$ & $\begin{array}{l}0.010 \\
(1.42)\end{array}$ & $\begin{array}{l}0.017 \\
(1.19)\end{array}$ & $\begin{array}{l}-0.001 \\
(0.66)\end{array}$ & $\begin{array}{l}0.001 \\
(0.81)\end{array}$ & $\begin{array}{l}-0.001 \\
(0.68)\end{array}$ & $\begin{array}{l}0.001 \\
(0.93)\end{array}$ & $\begin{array}{l}-0.001 \\
(1.39)\end{array}$ & $\begin{array}{l}0.001 \\
(0.93)\end{array}$ \\
\hline Mature-stage & $\begin{array}{l}0.044 \\
(0.75)\end{array}$ & $\begin{array}{c}-0.545^{* * *} \\
(4.34)\end{array}$ & $\begin{array}{l}0.115 \\
(1.46)\end{array}$ & $\begin{array}{c}0.029^{*} \\
(1.82)\end{array}$ & $\begin{array}{c}0.043 * * \\
(2.52)\end{array}$ & $\begin{array}{l}0.042 \\
(1.33)\end{array}$ & $\begin{array}{c}0.094 * * * \\
(3.77)\end{array}$ & $\begin{array}{l}0.022 \\
(1.40)\end{array}$ & $\begin{array}{c}0.093 * * * \\
(3.82)\end{array}$ \\
\hline Old-stage & $\begin{array}{l}0.012 \\
(0.13)\end{array}$ & $\begin{array}{c}-1.035^{* * *} \\
(6.65)\end{array}$ & $\begin{array}{l}0.215 \\
(1.29)\end{array}$ & $\begin{array}{c}0.076 * * * \\
(2.79)\end{array}$ & $\begin{array}{c}0.096 * * * \\
(3.46)\end{array}$ & $\begin{array}{l}0.070 * \\
(1.77)\end{array}$ & $\begin{array}{c}0.136 * * * \\
(5.02)\end{array}$ & $\begin{array}{l}0.033 \\
(1.60)\end{array}$ & $\begin{array}{c}0.132 * * * \\
(5.02)\end{array}$ \\
\hline TE/TA & $\begin{array}{l}0.463 \\
(0.76)\end{array}$ & $\begin{array}{c}-5.013 * * * \\
(10.92)\end{array}$ & $\begin{array}{l}-0.637 \\
(0.46)\end{array}$ & $\begin{array}{c}0.732 * * * \\
(11.57)\end{array}$ & $\begin{array}{c}0.828 * * * \\
(12.78)\end{array}$ & $\begin{array}{c}0.324 * * * \\
(4.10)\end{array}$ & $\begin{array}{c}0.222 * * * \\
(3.99)\end{array}$ & $\begin{array}{c}-0.259 * * * \\
(3.40)\end{array}$ & $\begin{array}{c}0.231 * * * \\
(4.40)\end{array}$ \\
\hline Profitability & $\begin{array}{c}2.230 * * * \\
(3.15)\end{array}$ & $\begin{array}{c}-2.470 * * \\
(2.04)\end{array}$ & $\begin{array}{l}0.896 \\
(0.80)\end{array}$ & $\begin{array}{l}0.255 \\
(1.35)\end{array}$ & $\begin{array}{c}0.389 * * \\
(2.09)\end{array}$ & $\begin{array}{l}-0.312 \\
(1.00)\end{array}$ & $\begin{array}{l}-0.047 \\
(0.17)\end{array}$ & $\begin{array}{l}-0.202 \\
(0.76)\end{array}$ & $\begin{array}{c}-0.077 \\
(0.31)\end{array}$ \\
\hline Investment opportunities & $\begin{array}{c}0.330 * * * \\
(4.92)\end{array}$ & $\begin{array}{c}-0.250 * * \\
(2.06)\end{array}$ & $\begin{array}{c}0.239^{*} \\
(1.74)\end{array}$ & $\begin{array}{c}0.046^{* * * *} \\
(2.72)\end{array}$ & $\begin{array}{c}0.067 * * * \\
(3.72)\end{array}$ & $\begin{array}{l}0.002 \\
(0.07)\end{array}$ & $\begin{array}{l}-0.032 \\
(1.36)\end{array}$ & $\begin{array}{l}-0.016 \\
(0.63)\end{array}$ & $\begin{array}{l}-0.026 \\
(1.24)\end{array}$ \\
\hline Firm size & $\begin{array}{c}-0.026 \\
(0.76)\end{array}$ & $\begin{array}{l}0.025 \\
(0.46)\end{array}$ & $\begin{array}{c}0.126^{*} \\
(1.92)\end{array}$ & $\begin{array}{l}-0.011 \\
(1.28)\end{array}$ & $\begin{array}{l}-0.002 \\
(0.18)\end{array}$ & $\begin{array}{c}-0.030^{* *} \\
(2.02)\end{array}$ & $\begin{array}{l}0.012 \\
(1.09)\end{array}$ & $\begin{array}{l}0.011 \\
(1.06)\end{array}$ & $\begin{array}{l}0.011 \\
(1.08)\end{array}$ \\
\hline Size dummy & $\begin{array}{c}-0.203^{*} \\
(1.89)\end{array}$ & $\begin{array}{l}-0.299 \\
(1.60)\end{array}$ & $\begin{array}{l}-0.500 \\
(1.33)\end{array}$ & $\begin{array}{l}0.026 \\
(1.07)\end{array}$ & $\begin{array}{l}0.002 \\
(0.07)\end{array}$ & $\begin{array}{l}-0.008 \\
(0.14)\end{array}$ & $\begin{array}{l}-0.062 \\
(1.42)\end{array}$ & $\begin{array}{l}-0.011 \\
(0.51)\end{array}$ & $\begin{array}{l}-0.062 \\
(1.43)\end{array}$ \\
\hline Asset tangibility & $\begin{array}{c}-0.444 * * \\
(2.20)\end{array}$ & $\begin{array}{l}0.090 \\
(0.18)\end{array}$ & $\begin{array}{l}-0.573 \\
(1.47)\end{array}$ & $\begin{array}{c}-0.100^{*} \\
(1.68)\end{array}$ & $\begin{array}{c}-0.148 * * \\
(2.31)\end{array}$ & $\begin{array}{l}0.022 \\
(0.22)\end{array}$ & $\begin{array}{l}-0.100 \\
(1.43)\end{array}$ & $\begin{array}{l}0.066 \\
(1.02)\end{array}$ & $\begin{array}{l}-0.098 \\
(1.44)\end{array}$ \\
\hline $\begin{array}{l}\text { Cash flow uncertainty } \\
\text { Leverage }\end{array}$ & $\begin{array}{l}-0.919 * * \\
(2.28) \\
-1.158 * \\
(1.83)\end{array}$ & $\begin{array}{c}2.657 * * * \\
(2.94)\end{array}$ & $\begin{array}{c}-0.372 \\
(0.56) \\
-1.022 \\
(0.78)\end{array}$ & $\begin{array}{l}-0.183 \\
(1.08)\end{array}$ & $\begin{array}{c}-0.296^{*} \\
(1.70)\end{array}$ & $\begin{array}{c}-0.787 * * \\
(2.53)\end{array}$ & $\begin{array}{c}-1.119 * * * \\
(3.67)\end{array}$ & $\begin{array}{l}-0.078 \\
(0.48)\end{array}$ & $\begin{array}{c}-1.091 * * * \\
(3.75)\end{array}$ \\
\hline Cash & $\begin{array}{c}-0.226 \\
(0.49)\end{array}$ & $\begin{array}{c}-1.636 * * * \\
(3.04)\end{array}$ & $\begin{array}{l}-0.403 \\
(0.48)\end{array}$ & $\begin{array}{c}0.214^{*} \\
(1.87)\end{array}$ & $\begin{array}{c}0.218^{*} \\
(1.74)\end{array}$ & $\begin{array}{l}-0.055 \\
(0.40)\end{array}$ & $\begin{array}{l}-0.150 \\
(1.47)\end{array}$ & $\begin{array}{c}-0.405^{* *} \\
(2.34)\end{array}$ & $\begin{array}{l}-0.142 \\
(1.64)\end{array}$ \\
\hline Chaebol & $\begin{array}{l}-0.059 \\
(0.75)\end{array}$ & $\begin{array}{c}-0.126 \\
(0.75)\end{array}$ & $\begin{array}{l}-0.051 \\
(0.36)\end{array}$ & $\begin{array}{l}0.012 \\
(0.55)\end{array}$ & $\begin{array}{l}-0.006 \\
(0.26)\end{array}$ & $\begin{array}{l}0.050 \\
(1.42)\end{array}$ & $\begin{array}{l}-0.005 \\
(0.18)\end{array}$ & $\begin{array}{l}-0.023 \\
(1.24)\end{array}$ & $\begin{array}{l}-0.003 \\
(0.14)\end{array}$ \\
\hline Time dummies & Yes & Yes & Yes & Yes & Yes & Yes & Yes & Yes & Yes \\
\hline Industry dummies & Yes & Yes & Yes & Yes & Yes & Yes & Yes & Yes & Yes \\
\hline Observations & 1,135 & 1,135 & 1,135 & 1,135 & 1,135 & 1,135 & 1,086 & 1,057 & 1,135 \\
\hline \multirow[t]{2}{*}{ R-squared } & 0.372 & 0.679 & 0.092 & 0.538 & 0.619 & 0.082 & 0.138 & 0.159 & 0.138 \\
\hline & \multicolumn{9}{|c|}{ Tests for differences across RE/TE lifecycle stages } \\
\hline Mature vs. old & & $* * *$ & & $*$ & $* *$ & & $* *$ & & $* *$ \\
\hline
\end{tabular}




\begin{tabular}{|c|c|c|c|c|c|c|c|c|}
\hline \multicolumn{9}{|c|}{$\begin{array}{l}\text { This table reports pooled ordinary least squares estimates for a sample of } 238 \text { firms from India. We observe firms in years } \\
2005,2007 \text {, and } 2011 \text {. Test-statistics, calculated using standard errors clustered by firm are underneath each estimated } \\
\text { coefficient in parentheses. The dependent variable is dividends-to-assets }(\%) \text {, book debt, interest expense to assets (\%), and } \\
\text { Div/Commit, as indicated. We measure firm lifecycle using MLDA. We define all variables in Table } 1 \text {. Though unreported, } \\
\text { all regressions include an intercept term, industry, and time dummies. } * * *, * * \text {, and } * \text {, denotes statistical significance at the } 1 \text {, } \\
5 \text {, and } 10 \% \text { levels, respectively. }\end{array}$} \\
\hline \multicolumn{9}{|c|}{ Panel A: Regression estimates } \\
\hline & & \multicolumn{7}{|c|}{ Dependent variable is } \\
\hline & & \multicolumn{2}{|l|}{1} & 2 & & 3 & \multicolumn{2}{|c|}{4} \\
\hline & & \multicolumn{2}{|c|}{$\begin{array}{c}\text { Div/Assets } \\
(\%)\end{array}$} & \multicolumn{2}{|l|}{ Book debt } & $\begin{array}{c}\text { Int/Assets } \\
(\%)\end{array}$ & \multicolumn{2}{|c|}{ Div/Commit } \\
\hline \multicolumn{2}{|l|}{ Corporate governance } & \multicolumn{2}{|l|}{$\begin{array}{c}0.025^{* *} \\
(2.23)\end{array}$} & $\begin{array}{l}0.000 \\
(0.14)\end{array}$ & & $\begin{array}{l}-0.004 \\
(0.59)\end{array}$ & \multicolumn{2}{|c|}{$\begin{array}{l}0.001 \\
(1.17)\end{array}$} \\
\hline \multicolumn{2}{|l|}{ Growth-stage } & \multicolumn{2}{|l|}{$\begin{array}{l}0.260 \\
(1.01)\end{array}$} & $\begin{array}{c}-0.103^{* * * *} \\
(3.78)\end{array}$ & & $\begin{array}{c}-0.567 * * \\
(2.49)\end{array}$ & \multicolumn{2}{|c|}{$0.170 * * *$} \\
\hline \multicolumn{2}{|l|}{ Mature-stage } & \multicolumn{2}{|c|}{$\begin{array}{c}2.053 * * * \\
(6.21)\end{array}$} & $\begin{array}{c}-0.184 * * * \\
(6.74)\end{array}$ & & $\begin{array}{c}-0.858 * * * \\
(4.18)\end{array}$ & \multicolumn{2}{|c|}{$\begin{array}{c}0.335^{* * * *} \\
(7.31)\end{array}$} \\
\hline \multicolumn{2}{|l|}{ Shake-out/decline-stage } & \multicolumn{2}{|l|}{$\begin{array}{c}0.342^{*} \\
(1.85)\end{array}$} & \multicolumn{2}{|l|}{$\begin{array}{c}-0.070^{* * * *} \\
(2.72)\end{array}$} & $\begin{array}{l}-0.310 \\
(1.53)\end{array}$ & \multicolumn{2}{|c|}{$\begin{array}{c}0.074 * \\
(1.88)\end{array}$} \\
\hline \multicolumn{2}{|l|}{ Investment opportunities } & \multicolumn{2}{|c|}{$\begin{array}{c}0.350 * * * \\
(4.16)\end{array}$} & $\begin{array}{l}0.001 \\
(0.31)\end{array}$ & & $\begin{array}{l}0.013 \\
(0.51)\end{array}$ & & \\
\hline Firm size & & $\begin{array}{l}-0.008 \\
(0.12)\end{array}$ & & $\begin{array}{l}0.007 \\
(1.04)\end{array}$ & & $\begin{array}{c}-0.163 * * * \\
(3.23)\end{array}$ & & \\
\hline Asset tangibility & & $\begin{array}{c}-1.259^{* * *} \\
(2.25)\end{array}$ & & $\begin{array}{c}0.305^{* * *} \\
(5.52)\end{array}$ & & $\begin{array}{c}1.834 * * * \\
(4.06)\end{array}$ & & F*** \\
\hline Cash flow uncertainty & & $\begin{array}{r}-2.699 \\
(0.79)\end{array}$ & & $\begin{array}{c}-0.702 * * * \\
(3.32)\end{array}$ & & $\begin{array}{r}-1.243 \\
(0.54)\end{array}$ & & \\
\hline Cash & & $\begin{array}{l}0.335 \\
(0.26)\end{array}$ & & $\begin{array}{r}-0.042 \\
(0.57)\end{array}$ & & $\begin{array}{c}-1.373 * * \\
(2.55)\end{array}$ & & \\
\hline Leverage & & $\begin{array}{c}-3.066 * * * \\
(3.69)\end{array}$ & & & & & & \\
\hline Business group & & $\begin{array}{l}0.176 \\
(0.61)\end{array}$ & & $\begin{array}{l}-0.023 \\
(1.09)\end{array}$ & & $\begin{array}{l}0.151 \\
(0.83)\end{array}$ & & \\
\hline Time dummies & & Yes & & Yes & & Yes & & \\
\hline Industry dummies & & Yes & & Yes & & Yes & & \\
\hline Observations & & 342 & & 342 & & 342 & & \\
\hline R-squared & & 0.451 & & 0.373 & & 0.286 & & \\
\hline & & & Tes & r differences & ss ML & DA lifecyc & & \\
\hline $\begin{array}{l}\text { Growth vs. mature } \\
\text { Growth vs. so/decline }\end{array}$ & & & & & & & & \\
\hline Mature vs. so/decline & & $\frac{* * *}{\text { Pan }}$ & el B: Sam & $\frac{* * *}{\text { le description }}$ & & $* *$ & & \\
\hline & Firms & Obs & D-Payer & SR-Payer & Intere & st-Payer & Perio & verage \\
\hline & 238 & 342 & 0.99 & 0.08 & & .98 & 2005 , & , 2011 \\
\hline & Mean & Std. Dev & Min & 25 th & Median & 75th & 95th & Max \\
\hline Corporate governance & 60.42 & 10.08 & 31.92 & 53.85 & 60.13 & 67.44 & 76.67 & 86.92 \\
\hline Foreign ownership & 0.12 & 0.11 & 0.00 & 0.02 & 0.09 & 0.19 & 0.33 & 0.55 \\
\hline Div/Assets (\%) & 2.19 & 2.67 & 0.00 & 0.52 & 1.19 & 2.82 & 7.84 & 14.08 \\
\hline SR/Assets (\%) & 0.24 & 2.08 & 0.00 & 0.00 & 0.00 & 0.00 & 0.51 & 36.21 \\
\hline Book debt & 0.27 & 0.18 & 0.00 & 0.13 & 0.27 & 0.40 & 0.58 & 0.77 \\
\hline Interest/Assets (\%) & 1.95 & 1.46 & 0.00 & 0.75 & 1.68 & 2.86 & 4.54 & 7.31 \\
\hline Div/Total & 0.46 & 0.33 & 0.00 & 0.15 & 0.42 & 0.78 & 0.99 & 1.00 \\
\hline Div/Commit & 0.47 & 0.33 & 0.00 & 0.16 & 0.43 & 0.78 & 0.99 & 1.00 \\
\hline Div/Payout & 0.96 & 0.17 & 0.00 & 1.00 & 1.00 & 1.00 & 1.00 & 1.00 \\
\hline
\end{tabular}




\begin{tabular}{|c|c|c|c|c|c|}
\hline \multicolumn{6}{|c|}{$\begin{array}{l}\text { This table reports pooled ordinary least squares estimates for a sample of } 238 \text { firms from India. We observe firms in years } \\
2005,2007 \text {, and } 2011 \text {. Test-statistics, calculated using standard errors clustered by firm are underneath each estimated } \\
\text { coefficient in parentheses. The dependent variable is Dividends to assets (\%), Interest expense to assets (\%), Div/Commit. } \\
\text { High foreign ownership is one if foreign ownership is above-sample median. Each of cross-listing, size, and business } \\
\text { group is one if the firm is cross-listed abroad, a large firm, or belonging to a business group, respectively. We classify } \\
\text { firms as old if their age is above the sample median. Though unreported, all regressions include an intercept term, controls, } \\
\text { industry, and time dummies. } * * *, * * \text {, and *, denotes statistical significance at the } 1,5 \text {, and } 10 \% \text { levels, respectively. }\end{array}$} \\
\hline & \multicolumn{5}{|c|}{ Panel A: Dependent variable is Div/Commit } \\
\hline & $\begin{array}{c}\text { Foreign } \\
\text { ownership }\end{array}$ & $\begin{array}{l}\text { Cross- } \\
\text { listing }\end{array}$ & Size & $\begin{array}{c}\text { Business } \\
\text { group }\end{array}$ & Firm age \\
\hline $\begin{array}{l}\text { Corporate governance } \\
\text { Corporate governance * high foreign ownership } \\
\text { Corporate governance } * \text { cross listing } \\
\text { Corporate governance } * \text { size dummy } \\
\text { Corporate governance * business group } \\
\text { Corporate governance } * \text { old firms }\end{array}$ & $\begin{array}{l}0.000 \\
(0.16) \\
0.003 \\
(1.01)\end{array}$ & $\begin{array}{l}0.001 \\
(0.55)\end{array}$ & $\begin{array}{l}0.000 \\
(0.20)\end{array}$ & $\begin{array}{l}-0.001 \\
(0.43)\end{array}$ & $\begin{array}{l}0.001 \\
(0.23)\end{array}$ \\
\hline \multirow[t]{3}{*}{ R-squared } & 0.412 & 0.425 & 0.413 & 0.413 & 0.286 \\
\hline & \multicolumn{5}{|c|}{ Panel B: Dependent variable is Div/Assets (\%) } \\
\hline & $\begin{array}{c}\text { Foreign } \\
\text { ownership }\end{array}$ & $\begin{array}{l}\text { Cross- } \\
\text { listing }\end{array}$ & Size & $\begin{array}{c}\text { Business } \\
\text { group }\end{array}$ & Firm age \\
\hline $\begin{array}{l}\text { Corporate governance } \\
\text { Corporate governance * high foreign ownership } \\
\text { Corporate governance } * \text { cross listing } \\
\text { Corporate governance * size dummy } \\
\text { Corporate governance * business group } \\
\text { Corporate governance * old firms }\end{array}$ & $\begin{array}{c}0.011 \\
(0.89) \\
0.029 \\
(1.28)\end{array}$ & $\begin{array}{c}0.027 * * \\
(2.10) \\
\\
-0.019 \\
(0.87)\end{array}$ & $\begin{array}{c}0.022 * * \\
(2.06)\end{array}$ & $\begin{array}{l}0.032 \\
(1.42)\end{array}$ & $\begin{array}{c}0.044 * * \\
(2.45)\end{array}$ \\
\hline \multirow[t]{3}{*}{ R-squared } & 0.454 & 0.457 & 0.452 & 0.451 & 0.507 \\
\hline & \multicolumn{5}{|c|}{ Panel C: Dependent variable is Int/Assets (\%) } \\
\hline & $\begin{array}{c}\text { Foreign } \\
\text { ownership }\end{array}$ & $\begin{array}{l}\text { Cross- } \\
\text { listing }\end{array}$ & Size & $\begin{array}{c}\text { Business } \\
\text { group }\end{array}$ & Firm age \\
\hline $\begin{array}{l}\text { Corporate governance } \\
\text { Corporate governance * high foreign ownership } \\
\text { Corporate governance } * \text { cross listing } \\
\text { Corporate governance } * \text { size dummy } \\
\text { Corporate governance * business group } \\
\text { Corporate governance * old firms }\end{array}$ & $\begin{array}{l}-0.002 \\
(0.14) \\
-0.005 \\
(0.36)\end{array}$ & $\begin{array}{l}0.002 \\
(0.21)\end{array}$ & $\begin{array}{l}-0.003 \\
(0.36)\end{array}$ & $\begin{array}{l}0.006 \\
(0.57)\end{array}$ & $\begin{array}{l}0.003 \\
(0.34)\end{array}$ \\
\hline R-squared & 0.286 & 0.295 & 0.287 & 0.288 & 0.288 \\
\hline
\end{tabular}




\begin{tabular}{|c|c|c|c|c|c|}
\hline \multicolumn{6}{|c|}{$\begin{array}{l}\text { This table reports pooled ordinary least squares (POLS) and second-stage two stage least squares (2SLS) estimates for a sample of } 293 \text { firms from Korea. The sample } \\
\text { period is } 1998 \text { to } 2004 \text {. Test-statistics, calculated using standard errors clustered by firm are underneath each estimated coefficient in parentheses. The dependent } \\
\text { variable is dividends to assets }(\%) \text {, interest expense to assets (\%), Div/Total, Div/Commit, and Div/Payout, as indicated. Each of cross-listing, size, and business group } \\
\text { is one if the firm is cross-listed abroad, a large firm, or belonging to a business group, respectively. We classify firms as old if their age is above the sample median } \\
\text { Though unreported, all regressions include an intercept term, controls, industry, and time dummies. ***, }{ }^{* *} \text {, and } * \text {, denotes statistical significance at the } 1,5 \text {, and } 10 \% \\
\text { levels, respectively. }\end{array}$} \\
\hline & \multicolumn{5}{|c|}{ Firms classified by cross listing status } \\
\hline & \multicolumn{5}{|c|}{ Dependent variable is } \\
\hline POLS & Div/Total & Div/Commit & Div/Payout & Div/Assets (\%) & Int/Assets (\%) \\
\hline $\begin{array}{l}\text { Corporate governance } \\
\text { Corporate governance } * \text { cross listing }\end{array}$ & $\begin{array}{l}-0.000 \\
(0.24) \\
-0.001 \\
(0.85)\end{array}$ & $\begin{array}{l}0.001 \\
(0.92) \\
-0.000 \\
(0.02)\end{array}$ & $\begin{array}{l}-0.002 \\
(0.86) \\
0.002 \\
(0.83)\end{array}$ & $\begin{array}{c}0.009 * * \\
(2.21) \\
0.008 \\
(1.24)\end{array}$ & $\begin{array}{c}0.022 * * \\
(2.39) \\
-0.025 \\
(1.27)\end{array}$ \\
\hline R-squared & 0.528 & 0.606 & 0.090 & 0.330 & 0.549 \\
\hline 2 SLS & Div/Total & Div/Commit & Div/Payout & Div/Assets (\%) & Int/Assets (\%) \\
\hline $\begin{array}{l}\text { Fitted Corporate governance } \\
\text { Fitted Corporate governance * cross listing }\end{array}$ & $\begin{array}{l}-0.001 \\
(0.98) \\
-0.001 \\
(0.57)\end{array}$ & $\begin{array}{l}0.000 \\
(0.44) \\
0.001 \\
(0.54)\end{array}$ & $\begin{array}{l}-0.001 \\
(0.73) \\
0.002 \\
(0.70)\end{array}$ & $\begin{array}{l}0.008 * * * \\
(2.89) \\
0.008 \\
(1.63)\end{array}$ & $\begin{array}{c}0.015^{* * *} \\
(2.88) \\
-0.018 \\
(1.60)\end{array}$ \\
\hline \multirow[t]{3}{*}{ R-squared } & 0.509 & 0.582 & 0.059 & 0.305 & 0.638 \\
\hline & \multicolumn{5}{|c|}{ Firms classified by firm size } \\
\hline & \multicolumn{5}{|c|}{ Dependent variable is } \\
\hline POLS & Div/Total & Div/Commit & Div/Payout & Div/Assets (\%) & Int/Assets (\%) \\
\hline $\begin{array}{l}\text { Corporate governance } \\
\text { Corporate governance } * \text { size dummy }\end{array}$ & $\begin{array}{l}-0.000 \\
(0.37) \\
-0.000 \\
(0.06)\end{array}$ & $\begin{array}{l}0.001 \\
(1.10) \\
-0.001 \\
(0.54)\end{array}$ & $\begin{array}{c}-0.003 * \\
(1.68) \\
0.007 * * \\
(2.23)\end{array}$ & $\begin{array}{c}0.012 * * \\
(2.24) \\
-0.003 \\
(0.66)\end{array}$ & $\begin{array}{c}0.031 * * * \\
(3.49) \\
-0.058 * * * \\
(4.49)\end{array}$ \\
\hline R-squared & 0.527 & 0.605 & 0.096 & 0.328 & 0.561 \\
\hline 2SLS & Div/Total & Div/Commit & Div/Payout & Div/Assets (\%) & Int/Assets $(\%)$ \\
\hline $\begin{array}{l}\text { Fitted Corporate governance } \\
\text { Fitted Corporate governance * size dummy }\end{array}$ & $\begin{array}{l}-0.001 \\
(0.94) \\
-0.000 \\
(0.15)\end{array}$ & $\begin{array}{l}0.001 \\
(1.06) \\
-0.001 \\
(0.65)\end{array}$ & $\begin{array}{c}-0.003 * \\
(1.93) \\
0.007 * * * \\
(2.63)\end{array}$ & $\begin{array}{c}0.011 * * * \\
(3.14) \\
-0.004 \\
(1.00)\end{array}$ & $\begin{array}{c}0.023 * * * \\
(3.92) \\
-0.048 * * * \\
(5.44)\end{array}$ \\
\hline R-squared & 0.510 & 0.581 & 0.067 & 0.304 & 0.647 \\
\hline
\end{tabular}




\begin{tabular}{|c|c|c|c|c|c|}
\hline \multicolumn{6}{|c|}{$\begin{array}{l}\text { This table reports pooled ordinary least squares (POLS) and second-stage two stage least squares (2SLS) estimates for a sample of } 293 \text { firms from Korea. The sample } \\
\text { period is } 1998 \text { to } 2004 \text {. Test-statistics, calculated using standard errors clustered by firm are underneath each estimated coefficient in parentheses. The dependent } \\
\text { variable is dividends to assets }(\%) \text {, interest expense to assets (\%), Div/Total, Div/Commit, and Div/Payout, as indicated. Each of cross-listing, size, and business group } \\
\text { is one if the firm is cross-listed abroad, a large firm, or belonging to a business group, respectively. We classify firms as old if their age is above the sample median } \\
\text { Though unreported, all regressions include an intercept term, controls, industry, and time dummies. ***, } * * \text {, and *, denotes statistical significance at the } 1,5 \text {, and } 10 \% \\
\text { levels, respectively. }\end{array}$} \\
\hline & \multicolumn{5}{|c|}{ Firms classified by level of business group status } \\
\hline & \multicolumn{5}{|c|}{ Dependent variable is } \\
\hline POLS & Div/Total & Div/Commit & Div/Payout & Div/Assets (\%) & Int/Assets (\%) \\
\hline $\begin{array}{l}\text { Corporate governance } \\
\text { Corporate governance } * \text { business group }\end{array}$ & $\begin{array}{l}-0.002 \\
(1.22) \\
0.002 \\
(1.40)\end{array}$ & $\begin{array}{l}0.000 \\
(0.05) \\
0.002 \\
(1.29)\end{array}$ & $\begin{array}{c}-0.004 * * \\
(2.01) \\
0.005 * * \\
(2.06)\end{array}$ & $\begin{array}{l}0.005 \\
(0.87) \\
0.011^{*} \\
(1.81)\end{array}$ & $\begin{array}{c}0.037 * * * \\
(3.58) \\
-0.036 * * * \\
(3.18)\end{array}$ \\
\hline R-squared & 0.529 & 0.606 & 0.092 & 0.335 & 0.561 \\
\hline 2 SLS & Div/Total & Div/Commit & Div/Payout & Div/Assets (\%) & Int/Assets (\%) \\
\hline $\begin{array}{l}\text { Fitted Corporate governance } \\
\text { Fitted Corporate governance } * \text { business group }\end{array}$ & $\begin{array}{c}-0.002 * * \\
(2.06) \\
0.002^{*} \\
(1.65)\end{array}$ & $\begin{array}{l}-0.000 \\
(0.37) \\
0.002 \\
(1.48)\end{array}$ & $\begin{array}{l}-0.004 * * \\
(2.28) \\
0.005 * * \\
(2.49)\end{array}$ & $\begin{array}{c}0.004 \\
(0.95) \\
0.010^{* * *} \\
(2.62)\end{array}$ & $\begin{array}{l}0.027 * * * \\
(4.27) \\
-0.027 * * * \\
(3.72)\end{array}$ \\
\hline \multirow[t]{3}{*}{ R-squared } & 0.511 & 0.583 & 0.066 & 0.311 & 0.641 \\
\hline & \multicolumn{5}{|c|}{ Firms classified by firm age } \\
\hline & \multicolumn{5}{|c|}{ Dependent variable is } \\
\hline POLS & Div/Total & Div/Commit & Div/Payout & Div/Assets (\%) & Int/Assets (\%) \\
\hline Corporate governance & $\begin{array}{c}-0.002 * \\
(1.69)\end{array}$ & $\begin{array}{l}0.001 \\
(0.06)\end{array}$ & $\begin{array}{c}-0.002 * \\
(1.65)\end{array}$ & $\begin{array}{c}0.008 \\
(1.48)\end{array}$ & $\begin{array}{c}0.020^{* *} \\
(2.15)\end{array}$ \\
\hline Corporate governance $*$ old firms & $\begin{array}{c}0.002 * * \\
(1.99)\end{array}$ & $\begin{array}{l}0.001 \\
(0.93\end{array}$ & $\begin{array}{c}0.003^{*} \\
(1.70)\end{array}$ & $\begin{array}{l}0.004 \\
(0.88)\end{array}$ & $\begin{array}{l}-0.008 \\
(0.75)\end{array}$ \\
\hline R-squared & 0.533 & 0.612 & 0.081 & 0.364 & 0.548 \\
\hline 2 SLS & Div/Total & Div/Commit & Div/Payout & Div/Assets (\%) & Int/Assets (\%) \\
\hline Fitted Corporate governance & $\begin{array}{c}-0.002 * * \\
(1.96)\end{array}$ & $\begin{array}{c}-0.000 \\
(0.08)\end{array}$ & $\begin{array}{l}-0.002 \\
(1.35)\end{array}$ & $\begin{array}{c}0.007 * * \\
(2.00)\end{array}$ & $\begin{array}{c}0.019 * * * \\
(3.44)\end{array}$ \\
\hline Fitted Corporate governance $*$ old firms & $\begin{array}{c}0.002^{* *} \\
(2.20)\end{array}$ & $\begin{array}{l}0.001 \\
(1.25)\end{array}$ & $\begin{array}{c}0.003 * \\
(1.70)\end{array}$ & $\begin{array}{l}0.004 \\
(1.35)\end{array}$ & $\begin{array}{c}-0.017 * * * \\
(2.82)\end{array}$ \\
\hline R-squared & 0.521 & 0.599 & 0.061 & 0.337 & 0.642 \\
\hline
\end{tabular}


Appendix 1: Payout precommitment by size, business group, cross-listing status, and firm age: two-stage least squares estimates

This table reports pooled ordinary least squares (POLS) and second-stage two stage least squares (2SLS) estimates for a sample of 293 firms from Korea. The sample

period is 1998 to 2004. Test-statistics, calculated using standard errors clustered by firm are underneath each estimated coefficient in parentheses. The dependent

variable is dividends to assets (\%), interest expense to assets (\%), Div/Total, Div/Commit, and Div/Payout, as indicated. Each of cross-listing, size, and business group

is one if the firm is cross-listed abroad, a large firm, or belonging to a business group, respectively. We classify firms as old if their age is above the sample median.

Though unreported, all regressions include an intercept term, controls, industry, and time dummies. ***, **, and *, denotes statistical significance at the 1,5 , and $10 \%$

levels, respectively.

Industry median governance from first stage IV regression

$0.548 * * *$

$(3.72)$

R-squared from first stage IV regression

0.646

F-test instruments from first stage IV regression 


\begin{tabular}{|c|c|c|c|c|}
\hline \multicolumn{5}{|l|}{ Appendix 2: India } \\
\hline \multicolumn{5}{|c|}{$\begin{array}{l}\text { This table reports pooled ordinary least squares (POLS), firm random effects (RE), firm fixed effects (FE), and second- } \\
\text { stage two stage least squares (2SLS) estimates for a sample of } 238 \text { firms from India. We observe firms in years } 2005 \text {, } \\
2007 \text {, and } 2011 \text {. Test-statistics, calculated using standard errors clustered by firm are underneath each estimated } \\
\text { coefficient in parentheses. The dependent variable is dividends to assets. Each of cross-listing and size, and business } \\
\text { group is one if the firm is cross-listed abroad, or a large firm, respectively. We classify firms as old if their age is above } \\
\text { the sample median. Though unreported, all regressions include an intercept term, controls, industry, and time dummies. } \\
* * *, * * \text {, and } * \text {, denotes statistical significance at the } 1,5 \text {, and } 10 \% \text { levels, respectively. }\end{array}$} \\
\hline & \multicolumn{4}{|c|}{ Dependent variable is Dividends to assets (\%) } \\
\hline & POLS & $\mathrm{RE}$ & $\mathrm{FE}$ & $\begin{array}{l}\text { Second-stage } \\
2 \text { SLS }\end{array}$ \\
\hline Corporate governance & $\begin{array}{c}0.025^{* *} \\
(2.23)\end{array}$ & $\begin{array}{c}0.020^{* *} \\
(2.04)\end{array}$ & $\begin{array}{l}0.004 \\
(0.24)\end{array}$ & $\begin{array}{l}-0.034 \\
(0.06)\end{array}$ \\
\hline \multirow[t]{4}{*}{ R-squared } & 0.451 & 0.495 & 0.221 & 0.489 \\
\hline & \multicolumn{4}{|c|}{ Firms classified by cross listing status } \\
\hline & \multicolumn{4}{|c|}{ Dependent variable is Dividends to assets (\%) } \\
\hline & POLS & $\mathrm{RE}$ & FE & $\begin{array}{c}\text { Second-stage } \\
\text { 2SLS }\end{array}$ \\
\hline & $\begin{array}{c}0.027 * * \\
(2.10)\end{array}$ & $\begin{array}{c}0.023 * * \\
(2.09)\end{array}$ & $\begin{array}{l}0.019 \\
(1.12)\end{array}$ & $\begin{array}{l}-0.038 \\
(0.34)\end{array}$ \\
\hline Corporate governance $*$ cross listing & $\begin{array}{l}-0.019 \\
(0.87)\end{array}$ & $\begin{array}{l}-0.020 \\
(1.13)\end{array}$ & $\begin{array}{c}-0.060^{* *} \\
(2.23)\end{array}$ & $\begin{array}{l}0.033 \\
(0.40)\end{array}$ \\
\hline \multirow[t]{4}{*}{ R-squared } & 0.457 & 0.500 & 0.168 & 0.491 \\
\hline & \multicolumn{4}{|c|}{ Firms classified by firm size } \\
\hline & \multicolumn{4}{|c|}{ Dependent variable is Dividends to assets (\%) } \\
\hline & POLS & $\mathrm{RE}$ & $\mathrm{FE}$ & $\begin{array}{l}\text { Second-stage } \\
2 \text { SLS }\end{array}$ \\
\hline Corporate governance & $\begin{array}{c}0.022 * * \\
(2.06)\end{array}$ & $\begin{array}{l}0.010 \\
(0.86)\end{array}$ & $\begin{array}{c}0.036^{*} \\
(1.81)\end{array}$ & $\begin{array}{c}-0.072 \\
(0.59)\end{array}$ \\
\hline Corporate governance $*$ size & $\begin{array}{l}0.006 \\
(0.96)\end{array}$ & $\begin{array}{l}0.017 \\
(0.78)\end{array}$ & $\begin{array}{c}-0.061^{*} \\
(1.80)\end{array}$ & $\begin{array}{l}0.097 \\
(1.08)\end{array}$ \\
\hline \multirow[t]{4}{*}{ R-squared } & 0.452 & 0.500 & 0.138 & 0.493 \\
\hline & \multicolumn{4}{|c|}{ Firms classified by firm age } \\
\hline & \multicolumn{4}{|c|}{ Dependent variable is Dividends to assets (\%) } \\
\hline & POLS & $\mathrm{RE}$ & FE & $\begin{array}{c}\text { Second-stage } \\
\text { 2SLS }\end{array}$ \\
\hline Corporate governance & $\begin{array}{c}0.044 * * \\
(2.45)\end{array}$ & $\begin{array}{c}0.034 * * \\
(2.27)\end{array}$ & $\begin{array}{l}0.010 \\
(0.40)\end{array}$ & $\begin{array}{l}-0.077 \\
(0.62)\end{array}$ \\
\hline Corporate governance $*$ old firms & $\begin{array}{c}-0.041^{*} \\
(1.86)\end{array}$ & $\begin{array}{l}-0.028 \\
(1.46) \\
\end{array}$ & $\begin{array}{l}-0.009 \\
(0.27)\end{array}$ & $\begin{array}{l}0.092 \\
(1.02)\end{array}$ \\
\hline R-squared & 0.507 & 0.500 & 0.219 & 0.491 \\
\hline $\begin{array}{l}\text { Industry median governance from first stage 2SLS } \\
\text { regression } \\
\text { R-squared from first stage 2SLS regression } \\
\text { F-test instruments from first stage 2SLS regression }\end{array}$ & & & & $\begin{array}{c}0.503^{*} \\
(1.75) \\
0.048 \\
1.47\end{array}$ \\
\hline
\end{tabular}


